University of Louisville

ThinkIR: The University of Louisville's Institutional Repository

Electronic Theses and Dissertations

$5-1943$

\title{
Some phases of pioneer education on the Kentucky frontier with emphasis on Nelson County, 1785-1860.
}

Wenonah Maraman

University of Louisville

Follow this and additional works at: https://ir.library.louisville.edu/etd

Part of the Education Commons

\section{Recommended Citation}

Maraman, Wenonah, "Some phases of pioneer education on the Kentucky frontier with emphasis on Nelson County, 1785-1860." (1943). Electronic Theses and Dissertations. Paper 2010.

https://doi.org/10.18297/etd/2010

This Master's Thesis is brought to you for free and open access by ThinkIR: The University of Louisville's Institutional Repository. It has been accepted for inclusion in Electronic Theses and Dissertations by an authorized administrator of ThinkIR: The University of Louisville's Institutional Repository. This title appears here courtesy of the author, who has retained all other copyrights. For more information, please contact thinkir@louisville.edu. 


\title{
University of Louisville
}

\author{
Some Phases of Pione日r Education on the Kentucky \\ Frontier with Emphasis on Nelson County \\ $1785-1860$
}

\author{
A Dissertation \\ Submitted to the Foculty \\ Of the Graduate School of the University of Louisville \\ In Partial Fulfillment of the \\ Requirements for the Degree \\ - of Master of Arts
}

Department of Education

by

Wenonah Maraman

1943 
NAME OF STUDENT:

Wenonah Elizabeth Maraman

TITLE OF THESIS: SOME PHASES OF PIONEER EDUCATION ON

THE KENTUCKY FRONTIER WITH EMPHASIS

ON NELSON COUNTY 1785-1860.

APPROVED BY READING COMMITTEE COMPOSED OF THE

FOLLOWING MEMBERS:

C. A. Rubado

Hilda Threlkeld

W. C. Mallalieu

NAME OF DIRECTOR: J. J. Oppenheimer

DATE: $\operatorname{may} 13,1943$ 
Page

Introduction

Chapter

I Settlement of the Western Country 6

II Development of Legal and Public

Interest in Education

III The Life of the Frontier and the Schools

IV Influence of the Various Religious

Sects upon Education in Nelson County 53

$\nabla$ Noteworthy Teachers and Schools of Nelson County

Conclusion

Appendix 
INTRODUCT ION 


\section{INTRODUCT ION}

"Kentucky owed most of her remarkable intellectual development at an early age in her history, to the fact that at the close of the Revolutionary War in 1781 many of the most intellectual and cultivated of officers and soldiers in that war from the states of Virginia, New Jersey, Pennsylvania and Maryland - being unsettled in their homes and business by its great duration privations and calamities - sought new homes in the then richest land in the known world. Thus, the times and the country itself, the very life of hardship, selfdenial, and self-dependence, combined to make a race seldom equalled in the world for strength of intellect and will, physical and moral courage, personal prowess and personal endurance. Never did a population so small in numbers embrace so many giants in intellect, giants in daring and all but giants in physical proportions. $n 1$

That a great feeling for education was shown by these early settlers in Kentucky and by those of Nelson County in particular is the object of this work. Appreciation of the educational facilities established in Nelson County from its formation to 1860 would be hindered without some discussion of efforts along this line before either Kentucky, the state or Nelson, the County, were formed.

1. Lewis Collins, History of Kentucky, Vol. I, p. 5. 
It will be necessary, for a comprehensive picture of the educational opportunities, to begin with the pioneer, or fort schools of Kentucke ${ }^{l}$ and trace the development of schools through their various stages.

Kentucky to 1860, experienced a series of educational periods beginning with the fort schools and ending with an inadequately functioning public school system. These periods, of course, over lepped but could be as follows:

The Fort Schools 1775The 0ld Field or Subscription Schools 1785-

The County Academy or Seminary 1788-1810

The Private Academies 1810-1860

The Public School System 1838-1860

The fort sohool existed until the pioneers left the stations for their own land when the "The Old Field" or subsoription schools took their place. The subscription schools had its origin in the desire of a group of neighboring pioneers to provide some form of education for their children. It was purely a community project and extended, especially in outlying districts, through most of the other periods.

The first state aided attempt at education was the county academy begun in 1788 and this morement, though inefficiently handled, lasted until about 1810 .

The private academy supplanted the County Academy and

1. This is the spelling of the word as used by John Filson for his book of this perlod, The Discovery, Settlement and present state of Kentucke. 
was prominent in Kentucky from about 1810 until about 1890. They supplied a need for secondary education until the publio sohool system was functioning.

The common school, backed by the state, was begun in 1838 but for a period of ten years or more did little or nothing for the children of Kentucky. And throughout this period the private academies and subscription schools continued to educate the majority of pupils.

In Nelson County the work will deal with the eatablishment and growth of various types of schools and the effect on education of the several religious groups found within the county• 
CHAPTER I

SETTLENENT OF THE WESTERN COUNTRY 


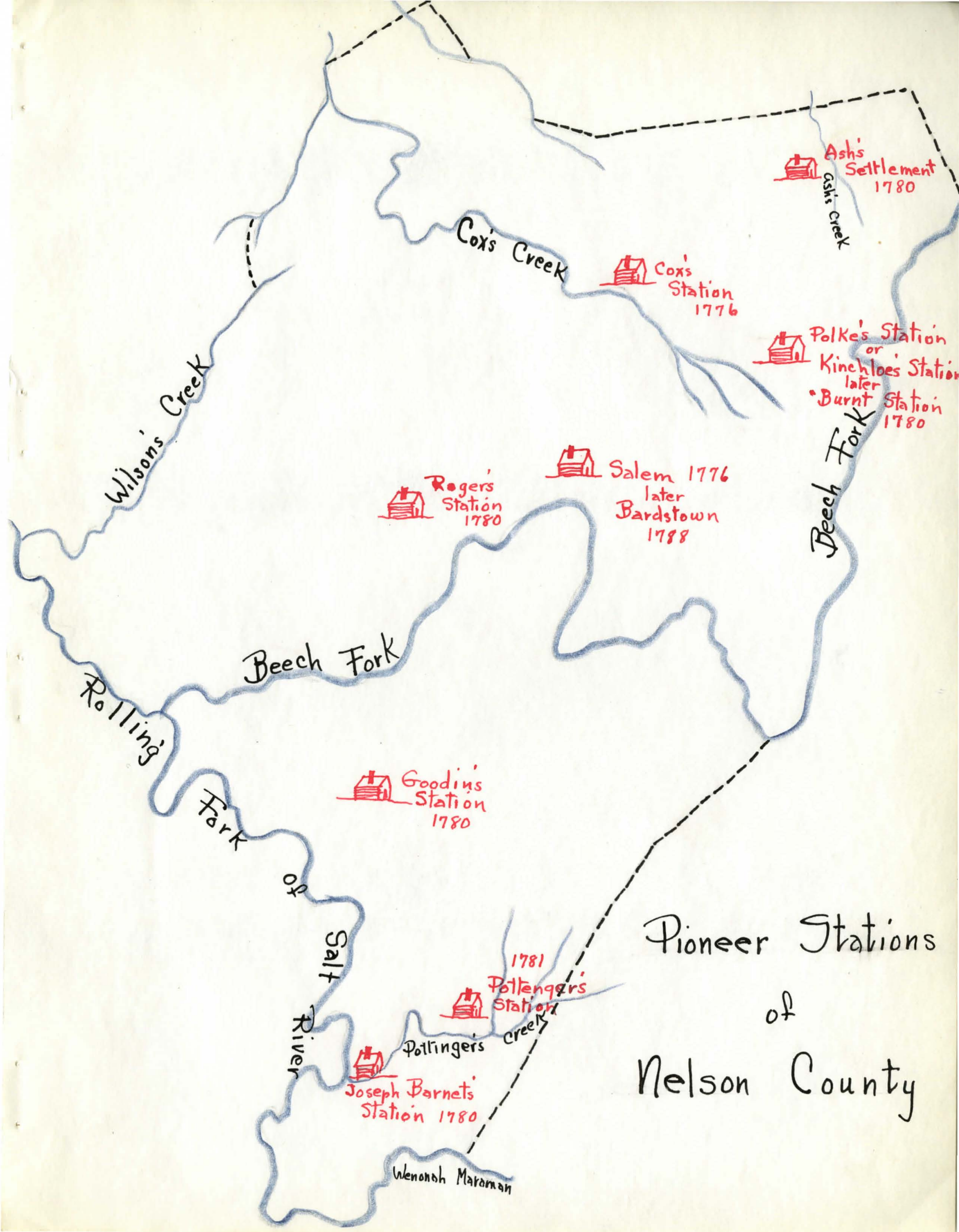




\section{CHAPTER I}

Settlement of the Western Country

As early as 1758 two obscure visits were made to Kentucky. A Dr. Walker ${ }^{1}$ came into the northeast portion in 1758 , and in 1769, Finley made a much more thorough examination of the same region. In the same year Daniel Boone and just a year later Captain James Knox made the two earliest visits that deserve particular mention. Their trips were more than mere visits for they stayed about two years. On their return news of their adventure spread throughout the western settlements of Virginia and North Carolina. Glowing descriptions of the now land, its inexhaustible fertility and beauty were spread afar.

Virginia had decided that bounty lands to be given to her troops should be located upon the western waters. Within less than two years after the return of Captain Knox and Daniel Boone surveyors were sent out to locate the land upon the ohio. Captain Bullitt, in 1773 , conducted a party of surveyors to the Falls of the ohio and from that position began the task of making surveys in various places.

In June of 1774, Captain James Harrod, 2 Abram Hite, Jacob Sandusky, James Sandusky and a party of thirty-seven others came down the Ohio until they reached the mouth of the

1. Lewis Collins, op.cit., Vol. I, p. 248.

2. Ibid., p. 17 . 
Kentuoky, and then up the Kentucky to a point that is now in Mercer County. There, in the summer, James Harrod erected a log cabin. This beginning grew into the fort and was named Harrodstown, later called Oldtown and now known as Harrodsburg.

Boonesborough, 1 the second fort, was built early in the spring of 1775. It was constructed under constant watch of the Indians who made sereral fierce attacks, but just five months after the completion of the fort, the first white women and children to stand on the banks of the Kentuoky River, came into the wilderness. They were Boone's wife and daughters.

From this time, Boonsborough and Harrodsburg became the nucleus and support of emigration and settlement in Kentucky.2

There were several important primeval trails or roads that led into and through Kentucky. Outstanding among these was the Warriors' Path. Generally it followed the ridges but occasionally dipped down into the ralleys. It was the most direot line of communication between the shawnee villages on the Solothe and the Cheroke villages on the Tennessee River. The Indians had used this trail for conturies.

A trail frequently used by the pioneers was the "Road from the old settlements in Virginia to Kentucke." 3 It was laid out by Daniel Boone and started at Flat Lick on the

1. Ibid., p. 249 .

2. Ibid.. p. 249.

3. Willard Rouse Jillson, Pioneer Kentucky, p. 39. Filson gave this title to the wilderness Trail. 
Cumberland and ran on into Boonesborough. The pioneers called it "Boone's Trail from the Yadkin to Boonesborough." Originally a buffalo trace, the Old Limestone Trail was followed by the Indians and early settlers. It led from a point were Limestone creek joins the ohio to Bryan's Station and on into Lexington.

John Filson'sl early map of Kentucky shows other important traces also. The Louisville Trace, The Licking Route and the Cumberland-Ohio Falls Trail were all used by the pioneers.

Harrodsburg, where the first school in Kentucky was held, was under the protection and guidance of James Harrod.

James Harrod was a man six feet high, well proportioned, and finely constructed, for strength and activity. His complexion was dark, animated, his conversation easily drawn out, his speech mild. Yet, could he but imperfectly read or write.

Before the establishment of schools and before the term education, was even known, aye, before letters were invented, or books or pens were made - the human heart was the seat of kindness - of generosity - of fortitude of magnanimity - and all the social virtues.

Then without knowing how to read or to write, James Harrod, could be kind and obliging to his fellow men - active, and brave in their defenco - dexterous in killing game, the source of supply. He could be captain over others as illiterate as himself; and $108 \mathrm{~s}$ endowed with the useful and benevolent qualities of the heart and of the head. 2

Humphrey Narshall, one of Kentucky's earliest historians, gives a picture of life in 1781.

1. While this map has many errors and irregularities, it is the most detailed and useable map that had been prepared up to the time it was made in 1784.

2. Humphrey Marshall, History of Kentucky, Vol. I, p. 23. 
The women did the offices of the household - milked the cows - cooked the mess - prepared the flax - spun, wore and made the garments of linen, or linsey: the men hunted and brought in the meat - they planted, ploughed, gathered in the corn - grinding it into meal at the handmill, or pounding it into hommony in the mortar, was occasionally the work of either; or the joint labour of both. The men exposed themselves alone to denger, they fought the Indians; they cleared the land, they reared the hut or built the fort, in which the women were placed for safety. . . Wooden vessels, either turned or coopered, were in common use. A tin cup was an article of delicate luxury, almost as rare as an iron fork. 1

Forts, or stations as they were called, were being built

and settlers spread throughout the new country. John Filson

had written his book, "The Discovery, Settlement and present

State of Kentucke," and made his map. The introduction to

this book is interesting.

We the subscribers, inhabitants of Kentucke and well acquainted with the country from its first settlement, at the request of the Author of this book, and map, have carefully revised them, and recommend them to the public, as exceeding good performances, containing as accurate a desoription of our country as we think can possibly be given; muoh preferable to any in our lonowledge extant; and think it will be of great utility to the publick. Witness our hands this 12 th day of May, Anno Domini 1784

Daniel Boon

Levi Todd James Harrod

Kentucky was growing:

- . at present divided into threo counties, Lincoln, Fayetto and Jefferson. - . There are at present eight towns laid off, and building; and more are proposed.

1. Ibid., p. 123 . 
Louisville, at the Fells of Ohio, and Beardstown are in Jefferson county; Harrodsburg, Danville and Boons-burrow, in Linooln county; Lexington, Lees-town and Greenville in Fayette county; the two last being on the Kentucke rirer.1

Gilbert Imlay has published in book form a series of

enlightening letters of this period.

Enigration to this country was mostly from the back parts of Virginia, Maryland, Pennsylvania, and North Carolina, until 1784; in which years many officers who served in the American army during the late war came out with their families; several families came also from England, Philadelphia, New Jersey, York and the New England States. The country soon began to be chequered after that era with genteel men, which operated both upon the minds and actions of the backwoods people, who constituted the first emigrants. A taste for decorum and elegance of the table was soon cultivated; the pleasures of gardening were considered not only as useful but amusing. These improvements in comforts of living and manners awakened a sense of ambition to instruct their youth in useful and accomplished arts.2

Along with this growth in refinement of living Imlay

describes other improvements.

An accurate account is kept of all male inhabitants above the age of sixteen, who are rated towards the expenses of the government by the name of tithables; from which, by allowing that so enrolled amount to a fourth part of the whole inhabitants, we may conclude that Kentucky contains, at present upwards of thirty thousand souls. Numbers are daily arriving, and multitudes expected this Fall; which gives a well grounded expeotation that the country will be exceedingly populous in a short time.

1. John Filson, op.c1t., p. 11

2. Gilbert Imlay, Topographioal Description of the Western Territory of North Ameriea, p. 153 . 
The inhabitants are, in general, polite, humane, hospitable and very complaisant. Being oollected from different parts of the continent, they have a diversity of manners, customs and religions, which may in time perhaps bo modified to one uniform. As yet united to the state of Virginia, they are governed by her wholesome laws, which are virtuously exeouted, and with excellent decorum. 1

On the first of January, 1785, all that part of Jefferson County "outh of Salt River became Nelson County."2 Ten years earlier settlers were building the pioneer forts or stations throughout this region.

In 1775 Colonel Cox, with seventeen others, came down the Ohio to the mouth of the Kentucky River; landed and made their way through the forest to Cox's Creek where they built their fort ealiod cox's station. 3

In the same year Jonah Eaton or Heaton, 4 with two companions, left Cox's Station and travelled down beyond Pottinger's Creek to the rich cane land, where they made a settlement.

During the fall or the spring of 1776, James Cox, Proctor Ballard and others made a settlement where Bardstown is now located. This settlement they called Salem until about 1792 when the name was changed to Bairdstown after David Baird, who owned the preemption on which the town was located. Filson's map of 1784 shows it to be a fortification with outlying cabins.5

1. Ibid., p. 300 .

2. Fumphrey Marshall, op.eit., Vol. I, p. 230.

3. John D. Wickliffe, "Pioneer Stations in Nelson County," The Filson Club History Quarterly, Vol. 2, p. 129.

4. Court records give both ways of spelling this name. 5. While Filson's map is inaccurate in several respects, this drawing of Bardstown, backed by other records, seems to be true. 
Captain Samuel Pottinger, a Rovolutionary War soldier, built his fort in 1781.1 Captain Pottinger and his family were from Prince George's County, Maryland. His station, in the southern portion of Nelson County, was one of the larger, permanent settlements and its founder one of the frontier's able defenders. Captain Pottinger served with both James and William Harrod before making his fort.

Bither 1779 or 1780 was the year in which Goodin's Station was established. This fort was built to the southwest of Bardstown between Rolling Fork and Beech Fork rivers.

Colonel Thomas Polke, in the spring of 1780, built Polke's Station three miles south of Bloomfield on the head branch of Simpson's Creok.2 Later this fort was called Kincheloo's Station and after the Indian attack on the night of September I, 1782, when most of the cabins were burned, the place became known as Bumt Station. Marshall gives an account of the destruction of this fort.

Colonel Floyd was ordered to take a party of militie to scour the country on Salt River.

Kincheloe's Station consisted of six or seven families. on the night of Sept. 1, 1782, the Indians fell on the place by surprise. They killed severel persons, men, women and ohildren when darkness of the night farored the escape of a few.

Among them was Mrs. Davis, whose husband was killed and another woman, who fled to the woods. There they were joined by a boy of twelve whose name was Ash. He was able to conduct them to Cox's station.

1. Mrs. William B. Ardery, (compiler) Kentucky in Retrospect, p. 172. 2. Lewis Collins, op.cit., Vol. II, p. 23. 
William Harrison, after placing his wife and a young woman under the floor of the cabin, escaped, as they did also, when the Indians left. Thompson Randolph, defended his family like a hero, he killed several Indians - his wife with an infant in her arms were killed by his side - his remaining child he put into the loft and escaped with it through the roof. 1

Roger's Station on Beech Fork of Salt River, a littlo to the southwest of Nazaroth, was built in 1780. Ashe's Station in northeastern Nelson County and Brashear's Station below the junction of Floyd's Fork of Salt River are also shown on Filson's map. While Mud Garrison, established on the present site of Shepherdsville in 1778, in Bullitt County, and Severn's Cabin, a settlement in Severn's Valley in Hardin County, were just over the Nelson County lines.

It was in these forts that we find Nelson's first school population. No doubt these pioneer children attended some sort of crude school, although we have no record of this fact.

Many of these people left the forts for their own land and stories of the bravery of men, women and children are many. This one is a good example of the courage displayed by these pioneers.

During the summer of 1787 , the house of $\mathrm{Mr}$. John Merrill, of Nelson County, Kentucky was attacked by the Indians, and defended with singular address and good fortune. Merrill, alarmed by the barking of a dog about midnight; opened the door. Ho received the fire of six or seven Indians, by which his arm and thigh were both broken. He instantly sunk upon the floor and called upon his wife to close

1. Humphrey Marshall, op.cit., Vol. I, p. 143. 
the door. This had scarcely been done when it was assailed by the tomahawks of the enemy, and a large breach soon affected. Mrs. Merrill, however, being a perfect Amazon both in strength and courage, guarded it with an axe and successively killed or badly wounded four of the enemy as they attempted to force their way into the cabin.

The Indians then ascended the roof, and attempted to enter by way of the chimney; but here again they were met by the same determined enemy. Mrs. Merrill seized the only feather bed which the cabin afforded, and hastily ripping it open, poured its contents upon the fire. A furious blaze and stifling smoke instantly ascended the chimney, and brought down two of the enemy, who lay for a few moments at the mercy of the lady. Seizing the axe, she quickly dispatohed them, was instantly afterwards summoned to the door, where the only remaining savage now appeared, endeavoring to effect an entrance, while Mirs. Merrill was engaged at the chimney. He soon received a gash in the cheek, which compelled him with a loud yell to relinquish his purpose, and return hastily to Chillicothe, where from report of a prisoner, he gave an exaggerated account of the fierceness, strength, and courage of the "long knife squaw."I

Michaux keptan interesting diary of his travels through

Kentucky. These notes which refer to Nelson County are of value

as records of that early time.

Sunday 14th of February, 1796

In all the Houses the children were suffering from Hooping Cough. This disease probably results from a simple cold but the reprehensible system of Living continually on salt and smoked meat fried in the pan produces these acrid humors that render expectoration more difficult. 2

One of the sources of early Nelson County history is its

first court records found in Minute Book A, 1785-1788. The court sat at Bardstown, the largest settlement. From the

1. Lewis Collins, op.cit., Vol. II, p. 644 .

2. Reuben Gold Thwaites, Early Western Travels,

Vol. 3, p. 92 . 
Minute Book, it is found that the court was much concerned with

petitions for roads.

On the petition of sundry inhabitants of the county praying for a road to be opened from Goodin's Station to the salt works. Ordered that Samuel Pottinger, Shadriok Carter, Siving Sprig, and Joseph Brown or any of the three of them being first sworn do view and report to the next court the most convenient way of opening and establishing the same.1

Bardstown, as the county seat, grew in importance as the

Minute Book shows. The criminals were to be taken care of by not one prison but two, one for the debtors and one for criminals. The public buildings were to be situated "in the square in the south street of Bardstown" - so decided the court.2

Jemes Morrison and Thomas Morton, gent, are appointed to contract with a workman for erecting stooks, pillory and whipping post for use of this county. 3

The diary of a traveller in 1788 gives a further description of the town.

May 12th, 1788. I arrived at Bardstown a little fatigued in consequence of our having made 30 miles today. I can say nothing of the town; it is night, and I put off till tomorrow speaking to you about it. The road is broad and quite pretty; had it not rained so long I believe it would have been charming.

13th. The town of Bardstown is not very large; there are, howewer, two or three stone houses and a court-house now building, which will be handsome and large and must cost very dear. I judge from this that the people of the place love lawsuits."

1. Minute Book A, Nelson County, Kentucky, May 24, 1785March 12, 1788, p. 9 .

2. Ibid., p. 21.

3. Ibid., p. 21.

4. Dr. Saugrain's Note Books, 1788, p. 13 . 
Some time later an appeal was made to the General Assembly

by the inhabitants of the town for aid in its regulation. In

1798 the following laws were passed.

That any citizen of said town raising swine within said bounds shall forfeit and pay the sum of two dollars, for each head of swine so raised and suffered to run at large.

That whosoever shall be guilty of running or racing horses in the streets or shooting at a mark within the limits of the town, he shall forfeit and pay the sum of six shillings.1

Bardstown, in the period between 1800 and 1820 , was in

many respects the leading town in the state. Young E. Allis on

gives it a vivid description.

Bardstown, the capital seat, was eren then the wonder town of the new west, although a village of probably not more than a thousand souls. It was peopled from Maryland, Virginia, Pennsylvania, with a streak of New York and New Jersey adventurers. It seothed with keon talents in law, politics, finance, and business. Mainly, the town was hot with law and politics. Bardstown lawyers were ruling the roost in the West. One James Buchanan, a graduate student of law, rode all the way from Lancaster, Penn., intending to begin practice in the Bardstown circuit. Arrived at Elizabethtown he went to the court-house and listened for two days to a group of Bardstown lawyers entering their pleas and arguing law and fact. Then he made up his mind that this was no place for a novice to seek cases, saddled his horse, and rode back to Lancaster, Penn. In 1856 he emerged thence to become president of the United States - an easier task then the conquest of the Bardstown bar. ${ }^{2}$

The population had increased and by 1810 numbered $821 .^{3}$ In the social, educational and cultural fields Bardstown was outstanding in the state by 1813 .

Vol. 2, p. 53 .

1. William Littell, The Statute Law of Kentucky,

2. Young E. Allison, A Chapter of Trappist History in Kentucky, p. 72 .

3. Lowis Collins, op.cit., Vol. II, p. 265. 
Bardstown ranked very high, in a social way, from its earliest years. Its people were refined, intelligent, wealthy and hospitable. Its excellent schools attracted many persons from abroad.- students seeking the advantages afforded by its learned facultios, and parents who sought a temporary residence near their children.l

Young E. Allison's account of this period is also indicative of its quality.

Socially the place was a curlous mixture of highrolling, high-thinking, high-laboring, high-gambling life. Many settlers had brought with them the refinements of the best social life. There were slaves to do the labor. The rough pioneer element was also in evidence. There were then living in the village young men who developed to become senators, attorney generals of the United States, secretaries of the Treasury, postmaster generals, foreign ministers men of high talent. Success there was its own diplome to be recognized anywhere.2

1. Lucius P. Little, Ben Hardin - His Times and Contemporaries, p. 161 .

2. Young E. Allison, op. cit., p. 73. 
CHAPTER II

DEVELOPMENT OF LEGAL AND PUBLIC INTEREST IN EDUCATION 
CHAPTER II

Development of Legal and Public Interest in Education

While Kentucky was still a county of Virginia provisions were being made for her welfare by that state. Of course, the patterns used were those of the mother state. Shaler tells us:

She owes to Virginia the most of the people she received during the half century when her society was taking shape, her institutions, be they good or evil, her ideals of life, her place in the nation's history, are all as immediately derived from her great mother Virginia as are an individual man's from the mother who bore him. I

We know the pioneers, while still living in the forts, attempted to give their children some schooling. These fort schools were Kentucky's first step towards education. Later when the settlers left the stations for their own land, the second step, the Old Field School, was established.

In 1775, Colonel Henderson called for delegates from the Kentucky settlements who met at Boonesborough. There was drawn up the first, brief code of nine laws which were to govern the young commonwealth. This was the first legislative body to meet west of the Alleghanies. Their code was as follows:

1. An act for regulating the militia

2.. An act for the punishment of criminals

3. An act to establish courts of judicature and regulating the practice therein

4. An act to prevent profane swearing and Sabbath breaking

5. An act for writs of attachment

6. An act for ascertaining clerk's and sheriff's fees

7. An act to preserve the range

8. An act for preserving the breed of horses

9. An act for preserving game. 2

1. N. S. Shaler, Kentucky - A Pioneer Commonwealth, p. 1 .

2. Ibid., p. 69 . 
This code is of interest as it points out the important feelings of the period. It betrays the fact that the breed of horses, the protection of game, the prevention of "profane swearing" and Sabbath breaking were uppermost in the minds of the delegates with no thought of aiding the education of their children apparent. True, it must be remembered that the excess of adult males in those early days was very great and while women and children did arrive with the first settlers their number was relatively much smaller than in a normal society. This fact may have helped diminish the need for provision for oducation.

But in 1780 "an Act to rest certain escheated lands in the county of Kentucky in trustees for a publick school" was passed.

Whereas it is represented to the general assembly, that there are certain lands within the county of Kentucky formerly belonging to British subjects, not yet sold under the law of escheats and forfeitures which might at a future day be raluable fund for maintenance and education of youth and it being the interest of this commonwealth always to promote and encourage every design which may tend to the improvement of the mind and the diffusion of useful knowledge even among its most remote citizens, whose situation a barbarous neighborhood and a savage intercourse might otherwise render unfriendly to science; Be it therefore enacted, That eight thousand acres of land, within the said county of Kentucke, late the property of Robert McKenzie, Henry Collins and Alexander McKie, be, and the same are hereby vested in william Fleming, William Christian, John Todd, Stephen Trigg, Benjamine Logan, John Floyd, John May, Levi Todd, John Cowan, Goorge Meriwether, John Cobbs, George Thomson, and Edmund Taylor, Trustees, as a freo donation from this commonwealth for the purpose of a publick sohool, or seminary of leaming, to be erected within the said 
County, and when the state of its funds will admit, and for no other use or purpose whatsoever: Saving and reserving to the said Robert McKenzie, Henry Collins, and Alexander McKie, and every one of them, and all and every person or persons claiming under them, or either of them, all right and interest to the above mentioned lands, or any part thereof to which they may be by law entitled, and of which they shall in due time avail themselves, any thing therein contained to the contrary notwithstanding. 1

The very wording of this earliest act is interesting as

it expresses feelings that foretell much for future educational

development on the Kentucky frontier. Just three years later,

1783, came the establishment of Transylvania Seminary.

Schools for education are formed, and a college is appointed by act of Assembly of Virginia, to be founded under the conduct of trustees in Kentucky, and endowed with lands for its use. An excellent library is likewise bestowed upon this seminary, by the Rev. John Todd of Virginia.2

But formation of this institution was not without handicaps.

We find the trustees, in a petition, asking for help:

June $3 r d, 1783$

To the Honorable General Assembly of Virginia

The petition of several of the trustees in whom certain escharted Lands in the County of Kentucky were vested for a public sohool, humbly sheweth,

- . That your Petitioners (a majority of the surviving Trustees) having convened for the purpose of carrying into execution the laudable design of the Legislature and finding themselves greatly embarrassed as to the manner of executing the Trust reposed in them, inasmuch as the Law does not declare whether a majority of the Trustees are sufficient to act, nor in case of Death of any of the members, how vacancies are to be filled up and it does not appear that the Trustees have power under their present appointment to receive

1. William Wall er Hening, Statutes at Large, Vol. 10, p. 288.

2. Gilbert Imley, op. cit., p. 300 . 
Donations from individuals or in any respect to forward so desirablo an Institution, without the Resolution of petitioning the Assembly, for an amendment of the Law, to an enlargement of the Powers of the Trustees; not doubting but that the same benevolent disposition which actuated the Assembly when this Donation was made will influence the present members of the Legislature chearfully to contribute as far as in them lies to the noble designs of deffusing useful knowledge and cultivating the unimproved minds of the South in every corner of the state. The sollicitous anxiety which discovers itself in the prinoipal Inhabitants of the county for having Sohools or Seminaries of Learning among them that their children may be educated as becomes a civilized people encourages your Petitioners to hope that the Liberality of private Individuals will be extended in aid of the public Donetions, were Trustees incorporated by Law ith power of perpetuating their succession, and authorized to purchase Estates, to receive Donations, make sale and conveyance of Land and to logislate for the Seminary in such Cases as are customary and under such restrictions and limitations as may be prescribed by Law.

Impressed with this hope and the full persuasion that the Assembly will listen with pleasure to every proposition that has a Tending to banish Ignorance and Error, and to introduce in their room what may polish the manners, encourage the improvement of the mind, promote liberality of sentiment and by refining give additional Incentives to Virtue. Your Petitioners pray that the Law may be amended in the sereral Cases herein before recited, and some fixt plan and form adopted which may be most conducive to the welfare and success of the Institution, and your Petitioners as in duty bound will ever pray etc. ${ }^{1}$

To estimate the influence and consequences which Transylrania, with its library, its leotures and its professors had upon the western country would be difficult. The intellect, morals and oulture of Kentucky pioneers were without doubt, elevated by such an institution within reach of many.

1. James Rood Robertson, Petitions of the Early Inhabitants of Kentucky to the General Assembly of Virginia. 1769-1792, The Filson Club Publications No. 27, p. 69 . 
In 1788, while Indian raids were erequent in Nelson County and most of the settlers were still gathered in forts which surrounded Bairdstownl another act was passed. This act incorporated Selem Academy, at Bairdstown, the second school to be established before Ientucky became a state.

Sec. I Thereas it is represented to this present general assembly, that many persons would make considerable donations to the seminary of learning at the place called Bairdstown, in the county of Nels on was a law to pass for incorporating the same: $B e$ it therefore enacted, That from and after the passing of this act, the said seminary shall obtain the name of Salem Academy, and that John Caldwell, Andrew Hynes, Isaac Morrison, Tarah Templin, Matthew Walton, John Steele, Philip Phillips, Walter Beall, George Harrison, James Baird, Joseph Barnet, James Morrison, James Allen, Cuthbert Harrison and William Taylor, gentlemen, be and they are hereby constituted $a$ body politic and corporate, by the name of the trustees of Salem Academy, and shall have perpetual succession and a common seal, and shall have power and capacity to purchase, receive and possess lands and tenements, goods and chattels, either in fee or any lesser estate therein, and the same to grant, let, sell, or assign, and to plead or be impleaded, prosecute and defend, all causes in law or equity.

sec. 2 The said trustees, or a majority of them, when assembled, shall have power to make such by-laws and ordinances as they shall think best for the good government of the academy, and to perform and do any thing respecting the property rested therein: . Provided such by-laws and ordinanoes shall not be contrary to the laws and constitutions of this commonwealth.

Sec. 3 They shall ohoose a president and secretary out of their own body: and in oase of vacancy by death or otherwise, of any one or more of the said trustees, the same shall be supplied by a majority of the remaining trustees.2

Shaler, one of Kentucky's early historians, says "We have

little concerning education in these early days. There were

1. This is the oldest spelling of the word, but "Beard's Town" is also frequently encountered in the old records. 2. William Littell, op.cit., Vol. 3, p. 579. 
no organized schools and the mass of the people received only a little household teaching." I of the first Constitution of the Commonwealth made in 1792, after Kentucky became a state, he says,

The most important omission of this constitution is the absence of any referenoe to a public school systen. The neglect of this need has been from the first, as it now is, a weak feature in the Kontuoky system of society.2

But to fill this need the legislature, in 1792, did authorize a series of academies to be soattered throughout the state. These were Kentucky Academy, at Pisgah, Woodford County, $1794 ; 3$ Franklin Academy, at Washington, Mason County, 1795 ; $^{4}$ and in 1798, Lexington Seminary in Fayette County, Jefferson Seminary in Jefferson County and Bethel Academy, a Methodist institution in Jessamine County. 5

Public favor was evidently behind this movement for by 1798, 30,000 acres of public domain had been provided for the use of academies. This was later increased to 114,000 acres. The act expresses the growing sentiment for education.

And whereas it is certain that however particular forms of government are better calculated then others to protect individuals in the free exercise of their natural rights, and are at the same time themselves better guarded against degeneracy, yet experience hath shewn tht even under the best forms, those entrusted with power have in time and by slow operation, perverted into tyrany, and it is believed that the most

1. N. S. Shaler, op.cit, , p. 118 .

2. Ibid., p. 123 .

3. William Littell, op.cit,. Vol. 1, p. 228.

4. Ibid., Vol. 1, p. 269 .

5. Ibid., Vol. 2, p. 174 . 
effectual means of preventing this, would be to illuminate as far as possible the minds of the people at large and more espeoially to give them knowledge of those facts which history exhibited, that, possesses thereby the experienoe of other ages and countries, they may be enabled to know ambition under all its shapes, and prompt to exert their natural powers to defeat its purposes:- whence it becomes expedient for promoting the public happiness, that those persons whom nature hath endowed with genius and virtue, should be rendered by liberal education, worthy to receive and able to guard the saored deposit of the rights and liberties of their fellow oitizens; and that to aid and accelerate this most desirable purpose, must be one of the first duties of every wise government. 1

'Nineteen aoademies, in as many counties, were to receire 6,000 acres of land each and it seems clear that the legislature intended to make provision for such schools as new counties were created.2 For some unknown reason Salem Academy receired 7,000 acres located in Christian county. 3

The seminaries or academies were controlled by the trustees, whose duties consisted of the selection of teachers, erection of needed buildings, and supervision of land granted by the state. They also had power to sell part of the land allotted them for the purpose of purchasing books, or "for such other purposes as may be necessary for the use and benefit of the said institutions." 4 This was the flaw whereby the abuse, the squandering of academy lands, was started.

The board of trustees also established courses of study,

1. Ibid., Vol. 2, p. 108.

2. Ibid., Vol. 2, p. 240.

3. Willard Rouse Jillson, Kentuoky Land Grants, The Filson Club Publications, No. 33, p. $23 \overline{3 .}$

4. William Littell, op.cit., Vol. 2, p. 334 . 
rules and regulations related to the school and its students, and made the selection of textbooks.

Most academies followed the custom of eastern states in that they taught the classical subjects, but it was left wholly to the discretion of the trustees just what should be taught, "whother the English language, writing, arithmetic, mathematios, and geometry only, or the dead and foreign languages and other scienoes." 1

An act of 1808 stated that within ten years after its passage the trustees should have established the academy and have at least twelve scholers or the 6,000 acres of land would revert to the commonwealth. ${ }^{2}$ But the seminary lands remained tax free as long as they remained the property of the seminaries. 3

The academies were located either at the county seat or in the principal town, which made them largely inaccessible to the majority of pupils throughout the county.

Although public sentiment had been strongly for the academies, this feeling underwent a change when it beame apparent that the mass of children was not being given educational advantages. The public also realized that in many cases the trustees were misusing the land grants. Thus the county academy movement began its decline.

By 1821 pritrate seminaries began to take the place of the

1. Ibid., Vol. 2, p. 243.

2. Ibid., Vol. 2, p. 245.

3. Ibid., Vol. 2, p. 107. 
public academies. Religious denominations, stock companies, and private individuals owned and controlled the private academies. The Presbyterians, Baptists, Christians and Methodists ${ }^{1}$ led the Frotestant denominations in the establishment of schools throughout the state while the catholic church began their parochial schools in the communities which were centers of catholic population.

Several governors, in the period 1807 to 1820 , included the need of a system of common schools in their messages to the legislature.2 The question was the subject of debate for prominent political leaders. Ben Hardin, one of Nelson's most able lawyers, was strongly opposed to such a plan. He was opposed to the establishment of schools maintained by law for he thought such system unjust to certain religious groups who could patronize only those schools conducted by teachers of their own faith. He also felt that the system would fail since good teachers could not be obtained. He conceded that common schools might benefit the towns but that the plan was very impractical for the rural districts.

I am confident, he said, that the county will not approve the system. It may be an advantage to the towns, but it will be a burden to the country, to which they should not, in justice, be asked to yield. The towns should remember the old saying: 'If, when you go to market, you expect to get meat, you must expect to get bones also.' They must expect their

1. Moses Edward Ligon, op.cit., p. 40.

2. Governors Greenup, scott, shelby, and slaughter stressed this feeling in their addresses. 
share of the inconveniences as well as advantages by living in towns. 1

In 1821 the legislature passed a law $^{2}$ whose purpose was to distribute a fund in just proportion to all counties for a system of general education. Information relative to the subjeot was colleoted and analyzed by a committeo.3 Then a plan for common schools was submitted. The report made by this group was an excellent piece of work.

Report of the Committee on Education in the House of Representatives, Session of 1823.

- - therefore, it is at once the interest and duty of government to afford facilities for education. The Beneral diffusion of scholastic instruction cannot be expected from the spontaneous and unassisted efforts of the people. The rich, it is true, can educate themselves, but the poor, and those in moderate oiroumstanoes, must depend, in a great measure, for the means of information, upon tho care and assistance of a parental goverment.

In Kentucky, the experiment has never yet been made, only because the population has not heretofore been deemed sufficiently dense homogeneous, nor the condition of the people so much diversified by the inequalities of fortune, as to render its adoption expedient or necessary.

It is all-important, that the experiment of common sohools, whenever made, should be successful. A failure in the first instance, might discourage future attempts, and be fatal to the ultimate results. 4

Circulars were sent to various states asking for information concerning the schools throughout the country. Two of the replies are worth quoting. From John Adams come this message:

1. Luoius P. Little, op.oit., p. 527.

2. Barksdale, Hamlett, History of Eduoation in Kentucky, p. 4.

3. The committeo was composed of Hon. W. T. Barry, Hon. John Pope, David R. Murray, John R. Witherspoon, David White, Jr. and William R. Roper.

4. George Robertson, Scrap Book on Law and Politics, Men and Things, p. 42 . 
The wisdom and generosity of your Legislature in making liberal appropriations of money for the benefit of Schools, Academies, Colleges, and the University are an equal honor to them and their constituents; a proof of their veneration for literature and science, and a portent of great and lasting good to North and South Americe, and to the World.

Great is truth - great is liberty, and great is humanity, and they must and will prevall. I have communicated your letters to as many of my friends as I have seen, and requested them to assist me in complying with your views. If the taper thread of life should continue to burn a little longer. I hope that you will hear more from me. At present Blind and paralytic, I am incapable of research or search. I can only give hints from memory. A law in this colony, almost two hundred years ago, obliged every town to maintain a school-master, capable of teaching the Greek and Roman languages, as well as reading, writing and arithmetic in English. These school-masters were to be examined by the Clergymen and Magistrates; and the Clergymen in those days were learnod men. This law is in force to this hour, though not so punctually exeouted as it used to be. I had myself the honor to be a schoolmaster from 1755 to 1758 in the town of Worcester, under this law.

Those schoolmasters and school-houses are maintained by taxes, roluntarily imposed on themselves by the people, in tow meeting, annually; and the ardor of the people in voting money for this noble purpose is astonishing. In the small town of Quincy, consisting of not more than 1,400 inhabitants, I think they roted this year $\$ 1,700$ for support of schools - more than a dollar a head for overy man, woman and child in the place.l

Mr. Jefferson replied as follows:

Your favor of the 15th June is received and I am very thankful for the kindness of its impressions respecting myself; but it ascribes to me merits which I do not olaim. I was only one of a band deroted to the cause of dependence, all of whom exerted equally their best endeavors for its success, and have a common right to the merits of its acquisition.

To the printed inquiries, respecting our schools, it is not in my power to give answer. Age, debility, on ancient dislocated and now stiffened wrist, render writing

1. Barksdale Hamlott, op. cit., p. 6 . 
so slow and painful that I an obliged to deoline everything possible requiring writing. An act of our Legislature will inform you of our plan of primary schools; and the annual reports show that it is becoming completely abortive, must be abandoned very shortly, after costing us $\$ 180,000$ and yet to cost us $\$ 45,000$ a year more, until it shall bo discontinued, and if a single boy has received the elements of common education, it must be in some part of the country not known to me.l

The legislature, in 1821, created a Literary Fund. Among other features, it stated that one-half of the profits of the Bank of the Commonwealth of Kentucky should be set aside and used for the support of a system of general education.

But by 1825 no system had been decided upon and the school fund was boing mismanaged. Robert wickliffe's letter to his constituents explains much about the project.

The majority have again appropriated the interest on the sehool fund to the payment of the ordinary expenses of the govennment. It seems now that those loud declaimers in favour of the education of the poor children never intended to establish district schools, but only held out this idea in their speeches and school committee correspondencies to reconcile the common people to their other extravagant paper projects. I roted this year as I did last, againet the appropriation of this fund, but the majority carried the measure, so that you may bid adieu to any prospect of District sohools in Kentucky - so long as she is governed by the triumvirs: They and their sustainers have too much use for money themselves to appropriate any to the education of poor schools.2

In 1830, after the legislature had heard various reports and discussions on the subject, a bill for general system of

1. Ibid., p. 6 .

2. Robert Wickliffe's Letter to His Constituents, p. 17. 
public sohools was introduced, enacted into law and approved by Governor Metoalf. The law did not create free schools, neither did it propose to educate the children of the State at public expense. The act did set aside the interest on an eight hundred and fifty thousand dollar sohool fund.1 This small fund was to act as an inoentire to the people. Each district was to impose a sufficient voluntary looal tax to educate its children. Part of the law required each district to organize, prooure a schoolhouse at its own expense and levy a tax in order to secure funds from the state.

This step was not received readily by the people. The fact that the schools of each county must be maintained by local taxes met with no approval. The people themselves were muoh more interested in political questions of the time than they were in education for their children by state methods. To them education still remained an individual or churoh obligation. Ben Hardin again made some interesting comments.

I have no opinion of free schools, anyhow - none in the world. They are generally under the management of a miserable set of humbug teachers, at best. The first teacher that a child has, when he starts with his $A, B, C$ or is learning to spell "bla, or baker" or "absolute", should be a first-rate soholar. He should know exactly how to spell and pronounce the English language; and should understand the art of composition and the construction of sentences. In the language of Dean Swift, he should have 'proper words, and they should bo put in proper places.'

1. Z. F. Smith, The History of Kentucky, p. 698 . 
The worst taught ohild in the world, is he who is taught by a miserable county school-master: and I will appeal to the experience of every man here, who ever went to those sohools, to say how hard it is to get clear of the habits of incorrect reading and pronouncing they have contracted at these county schools. For myself, I will say it cost me nearly as much labor as the study of the legal profession itself, to get clear of this miserable mode of pronouncing, contracted before I went to a collegiate school at the age of seventeen - your "would", and "could" and "should" and all that."

It was not until 1838 when the Hon. W. F. Bullock, 2 representative from Jefferson County, introduced a bill "to establish a system of common sohools in the state of Rentucky" that a permanent foundation for such a system was laid. Then, a large portion of funds received from the National Government was set aside and devoted to the purpose of educating the mass of Kentucky's children.

1. Lucius P. Little, op.cit., p. 555 .

2. George Baber, Origin of Popular Education in Kentucky, p. 11 . 
CHAPTER III

THE LIFE OF THE FRONTIER AND THE SCHOOLS 


\section{CHAPTER III}

The Life of the Frontier and the Schools

Few records have come down to us about the fort schools of Kentucky. The first physician, Dr. Hart, and the first school-teacher, Mrs. William Coomes were in Harrodsburg in 1776.1 Mrs. Coomes taught the fort school while her husband fought off Indian attacks. Little is known about this school but it is to be supposed that a few school books along with the Bible were brought over the mountains and these were used by Mrs. Coomes and her pupils.

These people lived with their rifles in their hands, and even the school-boys were required to carry their guns with them to school, as it was not known what emergency might arise in which the hands of the pupils might not be essential for their own protection. Amid such interruptions, they pursued their studies.2

Later Dr. Hart and Mrs. Coomes, who were Catholics, moved to Bardstown to be with those who were of like faith. But no record indicates that Mrs. Coomes ever taught again after moving to Nelson County.

At Boonesborough in 1779, Joseph Doniphon ${ }^{3}$ was teaching. These early teachers of the fort schools suffered all the hardships of the pioneers. John May, who taught at McAfee's station in 1777, was killed by the Indians in a fight upon the Ohio River.

1. Lewis Collins, op.cit., Vol. I, p. 22.

2. Z. F. Smith, op.cit., p. 670 .

3. Lowis Collins, op. oit., Vol. I, p. 515 . 
John Filson, who taught in lexington in 1783, lost his life in the forests of ohio. While a little later another teacherl was made prisoner by the Indians. After a short stay among the savages he made his escape and returned to Maysville. There his former pupils warmly welcomed him. No doubt if better records had been kept of this period, they would disclose stories of other teachers killed, schools broken up and pupils carried into captivity by the Indians. It took brave, hardy people to consider education at that time.

Taxes, after a time, were collected in the following manner: ${ }^{2}$ one shilling and eight-pence for every white servant, six pence halfpenny for every Negro, three-pence a horse, two shillings per hundred acres of land of the first class, cultivated or not, seventeen-pence per hundred for land of the second class and sixpence halfpenny for that of the third class. Numbers of those taxable were in arrears and none of that collected went for education. But Andre Michaux explains something about education after his travels west of the Alleghanies.

Throughout the western country the children are kept punctually at school where they learn reading, writing and the elements of arithmetic. These schools are supported at the expense of the inhabitants, who send for masters as soon as the population and their circumstances permit. 3

The schools referred to were those of the type known as "Old Field Schools." Rude log schoolhouses were built for the

1. 2. F. Smith, op.eit., p. 671.

2. Reuben Gold Thwaites, op.cit, Vol. 3, p. 242.

3. Ibid., p. 250. 
use of the neighborhood children. Some member of the community, usually an elderly man, was delegated to instruct them in the rudiments of reading, spelling, arithmetic and some music. These teachers generally were none too well grounded themselves and the course of instruction often ended with only the bare beginnings of an education.

Some of the teachers of the "Old Field Schools" were men of higher ability than those mentioned. Many were surveyors, then a lucrative and honorable calling. Such a person ran an advertisement in 1788 .

A single man who can be well recommended to teach Reading, Writing, Arithmetic and Bookkeeping, also Geometry, Trigonometry and Alegebra, after the most concise and expeditious Methods extant. He will engage in a private family or a compact neighborhood; He will also engage as a Deputy in the surveying business, he being well conversant in the practice of that branch. Gentlemen who would wish to employ him in Surveying may well be assured to have their lands regularly run, and will return accurate plotts with their content after the most modern methods of projection and Calculation. A few lines directed to Col. Patterson or the Printer will be duly attended to by C. Bolling. 1

Too often, the teacher, some stranger, a travelling Irishman, Englishmen or Yankee was one who was supposed to have some education due to the faot that he had travelled and seen a good deal of the world.

These teachers had to be expert pen-makers who fashioned the pupils' pens from quills with their sharp knives. The

1. Kentucky Gazette, Saturday, May 24, 1788 . 
instruction in writing consisted of "Capitals" and "large joining hand". 1 Arithmetic and geography were taught orally. And it is interesting to note that the geography lesson was often half-sung in doggerel verse. In the meantime those pupils who were not reciting added to the monotonous uproar of the room by studying aloud, as they were usually allowed to do. Practically no supervision was exercised over the teacher. As long as all went well within reason, the patrons offered no interference. The schoolmaster was usually paid in whiskey, bear bacon or some like commodity.2

We have the record of one such school that deserves attention for it gives a vivid description of education in about 1796.

Father and his neighbors were not indifferent to the education of their children; but they were all now settlers, all poor, and all illiterate, and hence, had not the means or conception nocessary to the establishment of a good school even had it been possible to procure a competent teacher. In a year or two after our removal a small log schoolhouse was erected by the joint labor of several neighbors, about half a mile north from his bouse, and just beyond the "line" of his place. It was entirely in the woods, but one of the wagon roads leading into the Lick passed by its very door. In winter, light was admitted through oiled paper by long openings between the logs; for at that time glass was not thought of. It was one story high, without any upper floor, and about sixteen by twenty feot in dimensions, with a great wooden ohimney, a broad puncheon floor, and a door of the same material, with its latch and string.

1. Alvin Fayette Lewis, History of Higher Education in Kentucky, p. 31.

2. Narthe Stephenson, History of Education in Kentucky, p. 70 . 
I give you these details, because they are equally descriptive of the common run of schoolhouses of that time. I never hoard of a reas on assigned for plaoing them generally by the road side; but travel was not great, and such was the insulation of families, that I fancy the children were, by common consent and mere social instinct, placed under circumstances to see all that could be seen; and, perhaps, as they occasionally saw new aspeots of things and persons, it was the bost plan.

The first teacher who wielded the hickory mace in this academy was Jacob Beadon. You will think his name in true harmony with the house. He was a recent immigrant from the eastern shore of Maryland, and an ample exponent of the state of society in that benighted region. His function was to teach spelling, reading, writing, and cyphering as far as the rule of three beyond which he could not go; and his attainments in that branch harmonized, as to qualify and compass, with his erudition in the others. Tho fashion was for the whole school to learn and say their lessons aloud, and a noisier display of emulation has perhaps never since beon made. This fashion was in those days common to all our schools, and although at first view, it may soem absurd and at variance with all improvement, something may be said on the other side. Two or more boys would get and say their spelling lesson together, and so of their reading lessons. The spelling book was Dilworth's, an old English production, which I would like to get hold of once more. The reading book was the New Testament, in which we read verse about. When the time for "letting out" was at hand, the whole school were called up to spell, and then came the strife of glory - the turning down and going up ahead. When dismissal was pronounced came the scramble for wool hats of all ages, sun bonnets, without pasteboard, of all materials, and dinner baskets of home manufacture. All the scholars brought their dinner and it was generally a social meal, with cronies and squads on the benches in winter - on old logs in the adjoining woods, at other seasons. The meal over, then came the play and romps, in many of which the boys and girls mingled together.l

1. Dr. D. Drake, Pioneer Life in Kentucky, p. 141. 
Considerable educational spirit is attested by this picture of the "Old Field Sohool," especially when one realizes that they were maintained with zeal in the midst of Indian attacks and other pioneer hardships, with perhaps occasional enoounters with wolves and wildcats.

After the erection of the schoolhouse the neighboring farmers proceeded to the business of "getting up" a school. The applicant for teacher would draw up an artiole of agreement, stating what branches he was able to teach and for what rate of compensation. We have an example of these articles in the following one written by the Rev. Devid Barrov.

An Artiole, Novr. 17th 1800.

To all whom it may concern. David Barrow of Montgomery Co'y and State of Kentucky, proposes teaching an english school the following Year, in a House to be ereoted on a Corner of Majr. J. Paine's Land on the Branch of Lulbegrud. To begin the first of January next, reserving to himself a cort Day in each Month, five Days at what is called Easter. Whitesuntide and Christmas, and ten Days at Harvest, which reduces the number of Sohool Days to 224, the Year, but in every Case he shall have the Liberty of teaching on the aforementioned Days and Times if he choses, and have his Vacations at any Season of the year that he thinks best; except the ten Days at Harvest, and shall make up no lost Time on Saturdays. He engages to give due Attendance, use the utmost impartiallity; have special regard to the Morals and Behaviour of the Pupils, and the best of his skills \& Judgment to forward them in the Arts of spelling, reading, writing, etc. For and in Consideration of which, he shall receive from subsoribers, for each scholar entered the Sum of $40 /$ One Fourth to be paid in Cash, the Remainder in Property, corn at $7 / 6$, Pork at $18 /$, Wheat $4 / 6$, Sugar at $1 /$, six hundred 
Linen at $3 /$, Dressed Flax at $7 /$, Dressed Herp $1 / 3$ and other Property as may be agreed on, to be paid and delivered at sd. Barrow's House on or before the last Day of December 1801. And if thro' Sickness or by any other Means the sd. Barrow should fail in the course of the year to reguarly to attend sd. School 224 Days, a Proportionable Deduction shall be made in the sum to be paid for each Scholar. And to prevent and settle any rexatious Disputes that may arise among the Employers concerning the sd. Barrow's conduct \& Management in sd. School, they shall nominate \& appoint from anong themselves three of most Disoreet \& fit Persons in their Judgment as Trustees, to whom all such Matters, and Things as respect the sd. Barrow's Conduct \& Management in sd. School shall be refered and their Determination in such case shall be final.

Rules for Sohool. Rules to be observed and strictly attended to in the Lulbegrud Reading School. 1st. The Teacher and Scholars to appear at the School House each Morning if possible, by half an Hour by Sun; with Hands and Face cleanly washed, and Hair neatly Combed.

2nd. Fires to be raised by the male Scholars in Rotation, according to Arrangement, the Hous $\theta$ to be Cleanly swept twice a Day, by the Females in the Same Manner.

3rd. The Scholars are to be particularly careful not to be dirty or tear their Books \& Cloaths. 4th. The Pupils are to be kind and civil to each other, and by no Means to call one another out of their proper vames.

5th. In sohool rime, each one is to keep his or her Seat, without necessary Reasons or Orders require the contrary, two are not to be absent at one Time, without Leave obtained or orders given; nor even one, without he or she bears the Token of Absence.

6th. Each one is to mind his or her Business during Book-Time; and there is to be no Fleering, Laughing, Hunching, Whispering, or making Mouths to provoke others during the Hours of Exercise. 7th. If any Scholar is at a Loss, and wants Instruction in any Word, or Part of his or her Lesson, they shall apply to the Master. 
8th. When the Scholars whether in or out of School, have Occasion to speak to or of the Master, it shall be with the Title of Mr. Barrow, and in like Manner to or of all married Persons and grown unmarried ones. Master \& Miss, with only their given Names, and when in Conversation with all such, the Terms Sir \& Madam are to be used.

9th. The Hours for Play or Diversion are from half after eleven, till one in the Winter, and 80 in Proportion as Days lengthen.

10th. Diversions at Play-Time are, Running, Jumping, Prison-bsse, Cat, and suoh others as the Master from Timo to Time shall admit, but Wrestling, Clinbing, and such as endanger Cloaths or Limbs will not be admitted.

1lth. Quareling, swearing, or cursing, Lieing, using Obsene Conversation, giving one another the Lie, and fighting will demerit the severest Kind of Punishment.

12th. The Girls are to exercize inosent Diversion to themselves.

13th. The Punishment for Transgressors are three, Viz. The Laugh-Block, Imprisonment \& the Rod.

14th. If after all necessary Means have been made use of, and there should be any scholar that cannot be broken of quarreling, Swearing, Cursing, etc., he shall with the advice of the prustees be expelled from the sohool.

15th. Additions to be made to the Rules, as Oocasion requires.

16th. No Scholar to be admitted, or allowed to continue in the school who has the Itch.

17th. The Scholars are not at Playtime or coming to or going from sehool unnecessarily to be Hallowing, Shouting, Nieing, or making fearful Outcries.

18th. The scholars are not to pilage one anothers School-Baskets, snatch Food from each other Hands or take from each other or any one else, any Thing which is not their own.

19th. If it appears necessary, a Monitor will be appointed from Time to Time to give Information of Disorder that may be committed out of School.I

1. "David Barrow and His Lulbegrud School, 1801," by Asa C. Barrow, The Filson Club History Quarterly, April, 1933, pgs. 88-93. Also photostat copy in The Filson Club. 
This article was passed from house to house for signatures and subscriptions. Usually the pay for the teacher was payable partly in money and partly in produoe. Many times the tuition of the poor was paid by public-spirited individuals who could afford the extra expense.1

The school terms were generally short, ten to fifteen weeks of six days each. But the school day was long, eight and even ten hours were not unusual.

Not much system was used in management or method of instruction. The children brought to school such books as they could obtain. In many cases none were accessible. But the alphabet could be learned from letters written upon a shingle with charcoal. No reference is found of the use of the horm-book in this section. Slates were used when they could be procured. The pupils studied in their own way with irreguler and incidental help from the instructor. The Bible was generally used as a reading book but an odd miscellany of volumes came from the cabins to be used as reading books also. The English Reader, or The Columbian Orator, Aesop's Fables, Gulliver's Travels, a Dream Book or even a badly worn Almanac would appear. A number of manuscript books upon arithmetic, surveying and geography have been found among the effects of pioneer families. The Filson Club has one such manuscript. 2

1. W. H. Venable, Beginnings of Literary Culture in the Ohio Valley, p. 192.

2. John Hargis made and used this book in teaching in Breathitt county, Kentucky. It is loaned to The Filson Club by Mrs. Ellen Hargis South. 
This arithmetic has 242 pages, is covered in heary, handstitched blue cotton and is $12 \frac{1}{2}$ inches in length by $7 \frac{1}{2}$ inches in width. It is boautifully written in black ink which has faded little. The titles are elaborately scrolled and shaded. Part of the title page is torn away but the rest reads as follows:

- - and contains all the useful or . . Rules and Examples in that Book. Rules and sundry examples which contained in Common Arithmetic. Such measuring as of Barrells, Keggs, Corncribs \&. Inserted in the most plain, easy and Concise manner now in use, particularly Inscribed for the use of the Teacher, or those who wish to study the Arithmetic Art.

Each new step begins with an explanation followed by a rule. The rule for simple addition is, "Begin at the right hand or first row, and add it upwards, take out one for every 10 \& carry them to the next row, and set down all orer the tens, \& so proceed to the last row \& then set down the full numbers.1

The more advanced work includes examples such as these:

Three Fools discoursing about their ages says A. I am 20 years Old; says B. I am as old as A. and half as C. C. says $I$ am as old as you both -..required -... each mans age ....

A Gentleman Bought a fish whose head was 6 inches long; and his tail was as long as his head and half his body, and his Body as long as his head and his tail both. Query, the length of fish $\ldots-\ldots 2$

But as early as 1798, Kentucky was able to publish some of her own school books. The Kentucky Primer and Kentucky Speller

1. Ibid., p. 3 .

2. Ibid., p. 133 . 
were printed at Washington, the old county seat of Mas on County. 1 Harrison's English Grammar was printed at Frankfort, while Western Selections, the Union Primmer and Horton's Arithmetic were printed in Lexington in 1805.

Newspepers were likewise adding to the cultural growth of the country.2 In Bardstown The Western American was published in 1803, The Impartial Review in 1806, The Candid Review in 1807 or 1808, and The Bardstown Repository in 1811. These pioneer newspapers were circulated throughout Nels on County. While even earlier, The Kentucky Gazette in 1787, and The Herald, in 1795 were published at Lexington. The Palladium, 1798, and The Western World, 1806, published at Frankfort, no doubt also found their way into Nelson County homes.

Books were not as scarce in Nelson County by 1808 as in earlier years. The Candid Review carried the following advertisement.

Books Lent or Taken

I will be greatly obliged to my acquaintances to return my Books which heve been borrowed. Any person having books belonging to me, in their possession, will have honesty enough. I hope, to return them. I will not lend my books. Wm. P. Duvall ${ }^{3}$

In Bardstown in 1811 the estate of Philip Quinton was settled. One hundred and seventy-four books were listed and sold to Quinton's son for $\$ 545.50 .4$

1. 2. F. Smith, op.cit., p. 673 .

2. "Check List of Kentucky Newspapers" - Mimeograph copy in The Fils on Club.

3. The Candid Review, March 22, 1808.

4. Will Book C, Nelson County, p. 37 . 
There was a period when education for girls was receiving scant attention and for a long time there were fow schools for girls in the state. Then girls had to attend schools of the most primitive kind where teachers "were often destitute both of a knowledge of polite literature and good manners." I In the period between 1806 and 1812, Kentucky could point to the following fow schools for girls: a grammar school at Paris opened by Rev. John Lyle, 1806 to 1809,2 and one at Washington Mason County, taught by Mrs. Louisa Fitzherbert, 1807 to 1812.3 Loretto Academy, Marion County, and Nazareth Academy, Nelson County, were begun in the same year, 1812. Of this group only Loretto and Nazareth survived. Nazareth, Loretto and later Science Hill, established at Shelbyville in 1825, were long the principal girl's schools, not only in Kentucky but in the southwest generally. The cost of education in one of these seleot schools is shown through the account of two girls, Margaret and Matilda Buckman. These children were the grand-daughters of Zachariah Maraman, the pioneer, who settled near Bardstown in 1785 or 1787 . The little girls were first students in the primary school at Gethsemani until it disbanded in 1848 , when they transforred to Loretto Academy. By 1850 the children were motherless and spent part of their vacation at Loretto. Their account includes the extras, music, painting and drawing. 4

1. 2. F. Smith, op.cit., p. 699 .

2. Lewis collins, op.cit., Vol. I, p. 483.

3. Alvin Fayette Letis, History of Higher Education in Kentucky, p. 34 .

4. Account of Misses Margaret and Matilda Buckman. Copied from Ledger, Loretto Motherhouse, Nerinckx, Kentucky. 
Misses Margaret and Matilda Buckman, daughters of Wim. Buckman in a/c with Loreto.

1849

Sept. 3 oct. 19 to one session Board \& tuition for each

" 4 months tuition in music for each

" 1 session drawing \& painting for each
Dr.

$\$ 88.00$

23.60

5.00

1850

Feb. 15 to 1 session board \& tuition in the above for each

Sept. 2 " 6 weeks board etc. for each in vacation

" 1 session board for each

" Bill of Sundries

123.00

12.00

123.00

15.00

1851

Feb. 15 to 1 session for both as above

"Bill of Sundries

July 15 " 2 weeks board in vacation for each

By balance of note \& int. on Geths emani

Aug. 2 By note

\begin{tabular}{rr}
123.00 & \\
3.00 & \\
4.00 & \\
\hline 520.35 & \\
& $\begin{array}{r}424.75 \\
95.60\end{array}$ \\
\hline 520.35 & 520.35 \\
\hline 118.00 & \\
6.00 & \\
.15 & \\
.35 & \\
\hline & 50.00
\end{tabular}

1852

Feb. 81 session for each

Fob. 15 Postage 10 Music $\$ 3.80$

118.00

March 6 Postage, April 16

3.90

.10

1.50

Recd. as payment in full for schooling up to Aug. 
An interesting custom related to education is found at an early date. It was no unusual occurence to run a lottery for the benefit of educational institutions. In 1791, such a lottery was in progress for Transylvania Seminary .

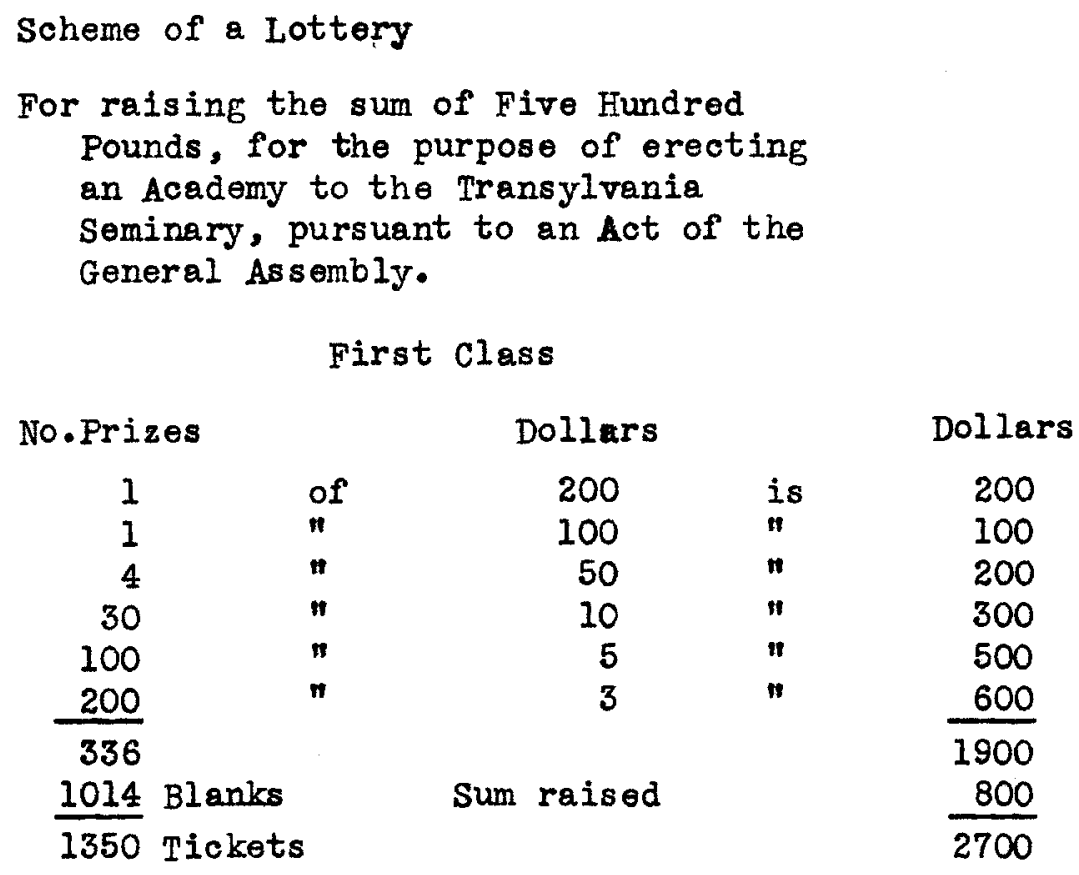

Second Class

\begin{tabular}{|c|c|c|c|c|}
\hline \multicolumn{2}{|c|}{ No.Prizes } & \multicolumn{2}{|l|}{ Dollars } & \multirow{2}{*}{$\begin{array}{c}\text { Dollars } \\
300\end{array}$} \\
\hline 1 & & 300 & is & \\
\hline 1 & & 200 & $m$ & 200 \\
\hline 2 & & 100 & $n$ & 200 \\
\hline 6 & & 50 & n & 300 \\
\hline 10 & & 30 & $n$ & 300 \\
\hline 40 & & 10 & n & 400 \\
\hline 100 & & 8 & $n$ & 800 \\
\hline 200 & & 4 & $n$ & 800 \\
\hline \multicolumn{4}{|c|}{$\begin{array}{l}1 \text { for the lst blank drawn } \\
1 \text { for the last blank ditto }\end{array}$} & $\begin{array}{l}17 \\
161 / 3 \\
\end{array}$ \\
\hline \multicolumn{4}{|c|}{$\begin{array}{l}362 \text { Prizes } \\
838 \text { Blanks }\end{array}$} & $\begin{array}{rr}3333 & 1 / 3 \\
866 & 2 / 3 \\
\end{array}$ \\
\hline \multirow[t]{3}{*}{1200} & \multicolumn{3}{|l|}{ Tickets } & 4200 \\
\hline & \multicolumn{3}{|c|}{$\begin{array}{l}\text { Sum raised in lst class } \\
\text { Sum raised in } 2 \text { nd class }\end{array}$} & $\begin{array}{l}800 \\
8662 / 3 \\
\end{array}$ \\
\hline & \multicolumn{3}{|c|}{ Equal to 500} & $16662 / 3$ \\
\hline
\end{tabular}


The sum of 5 per cent to be deducted from all prizes of 30 dollars and upwards, to defray the necessary expense attending the drawing of said Lottery.

All Prizes not demanded within 6 months after drawing shall be deemed generously given, and applied to the use of said Seminary.

Since the public good is the great and only object of this undertaking - Since the cultivation of the Moral virtues of the heart, as well as the advancement of the rising generation, is an object equally interesting to every good citizen; It is earnestly hoped that this Scheme will attract the attention and Patronage of the Public. The Lottery will be drawn as soon as the tickets are sold - Notice of the time and place will be published in the Kentucky Gazette - Tickets may be had of the subscribers, or at Mr. Bradford's Printing Office.

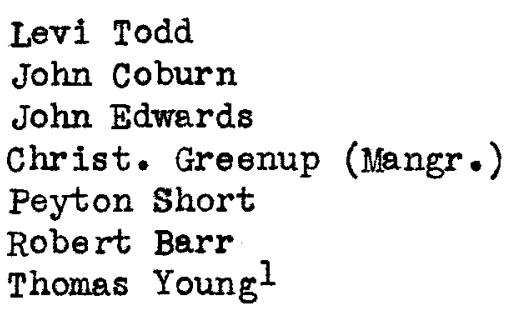

An orphan, infant or an apprentice was not to be denied educational advantages on the Kentucky frontier. The act of 1785 declares,

Every orphan who hath no estate, or not sufficient for a maintenance out of the profits, shall, by order of the court of the county in which he or she resides be bound apprentice, until the age of twenty-one years, if a boy, or eighteen years, if a girl, to some master or mistress, who shall covenant to teach the apprentice some art, trade, or business, to be particularized in the indenture, as also reading, and if a boy, cormon arithmetic, including the rule of three, and to pay him or her three pounds and ten shillings at the expiration of the time.

The court of every county, city or borough, shall at all time receive the complaints of

1. Kentucky Gazette, Saturday, June 18, 1791. 
apprentices, or hired servants, being citizens of any one of the confederate states of America, against their masters or mistreoses, alledging undeserved or immoderate correction, insufficient allowance of food, raiment, or lodgment, or want of instruction. 1

The Nels on County Minute Book for $1785-1788$ relates the stories of three orphan boys, one in particular, being put in the care of the schoolmaster.

June $28,1785^{2}$

William McLean an orphan boy now living with Stoffel Kirkandolphen to be bound to Isaac Morrison, gent., until he arrives at the age of Twenty-one years he the said Morrison using and providing for the said orphen according to Law.

September $29,1785^{3}$

A Bond from Young Ewing to John Moore for the convey of a lot in Bardstown was proved by John Moore, school master and William Bard and ordered to be recorded.

September $29,1785^{4}$

An application made by Isaac Morrison the former order of Court binding Wm. McLean an orphan Boy to said Morris on is recinded. Ordered that the above mentioned Orphan be bound to Christopher Kirkendolpher, who is to teach him to read and cipher, and the blacksmiths trade also to furnish him with sufficient meat, drink, washing and lodging according to Law.

April 26, $1786^{5}$

Ordered that John Faith, Orphan of William Faith be bound according to law to John Moore (Schoolmaster) until he comes of age, he being now twelve years old next June.

November $29,1786^{6}$

Ordered that Isaac Imlay, Orphant of Thomas Imlay, be bound to John Vantreese according to Law being twelve years old next April.

1. William Waller Hening, op.cit., Vol. 7, p. 197 .

2. Neloon County Minute Book $\bar{A}, 1785-1788$, p. 9

3. Ibid., p. 43 .

4. Ibid, , p. 46.

5. Ibid., p. 83.

6. Ibid., p. 125. 
An interesting paper is an indenture. Through just such an agreement many of Nelson's orphans may have learned a trade and perhaps acquired what little education they could in the subscription schools of their neighborhood. The indenture by which Archibald Pottenger was bound out to Joseph Philpott was dated August 12, 1797, and was probably among the first filed in the County Clerk's little office.

This indenture, made this Twelfth Day of August, Seventeen Hundred and Ninety-seven, between Joseph Philpott of the County of Green and the State of Kentucky, of the one part, and Archibald Pottenger, of the second part, Witnesseth that whereas the clerk of the County Court of Green County, Kentuoky, hath been ordered by the said court to bind out the said Archibald to the said Joseph Philpott to learn the art and mystery of a Shoemaker, Now, the said doth by these present covenant and agree to and with the said Archibald to teach him the art and mystery aforesaid and to read and write and also common arithmetic, including the Rule of Three; and that the expiration of the term of his service or when the said Arohibald arrives at the age of Twenty-one Years, the said Joseph doth covenant and agree to pay the said Archibald the sum of Three Pounds and Ten Shillings and also $a$ new and decent suit of clothes; and the said Archibald doth covenant and agree to serve the said Joseph until he arrives at the age of Twenty-one years in working at the trade aforesaid.1

During the years when public opinion was being formed as to the value of a common school system, education was the topic of much discussion. Frequent articles, on this subject, were submitted to the newspapers. A lengthy one was written by

1. Louisville Courier-Journal, October 20, 1926. Editorial page. 
"F", an extract from which points out a feature evidently

in controversy.

In this country, a very erroneous opinion pervades almost every class of the community relative to scholastic discipline. Any attempt to chastise on the part of the teacher, is immediately construed by the parent as a remnent of European tyranny incompatible with the principles of a republican government, calculated to blunt the edge of genuine valor and tromple under foot the seeds of native patriotism. 1

But at the small schoolhouses scattered throughout

Nelson County not all was hard rork. The schoolhouses were generally used for church sessions of any and all denominations and for other purposes too.

Sometime in the year, 1795 or 1796, the Catholics on Pottinger's creek got up a dancingschool, and employed an Irish Catholic as dancing master. The dancing-school was held on Saturday evening in a neighboring schoolhouse. 2

1. Western Herald, March 2, 1831.

2. M. J. Spalding, Sketches of Early Catholic Missions of Kentucky, 1787-1826, p. 69 . 
CHAPTER IV

THE INFLUENCE OF VARIOUS RELIGIOUS SECTS

UPON EDUCATION IN NELSON COUNTY 


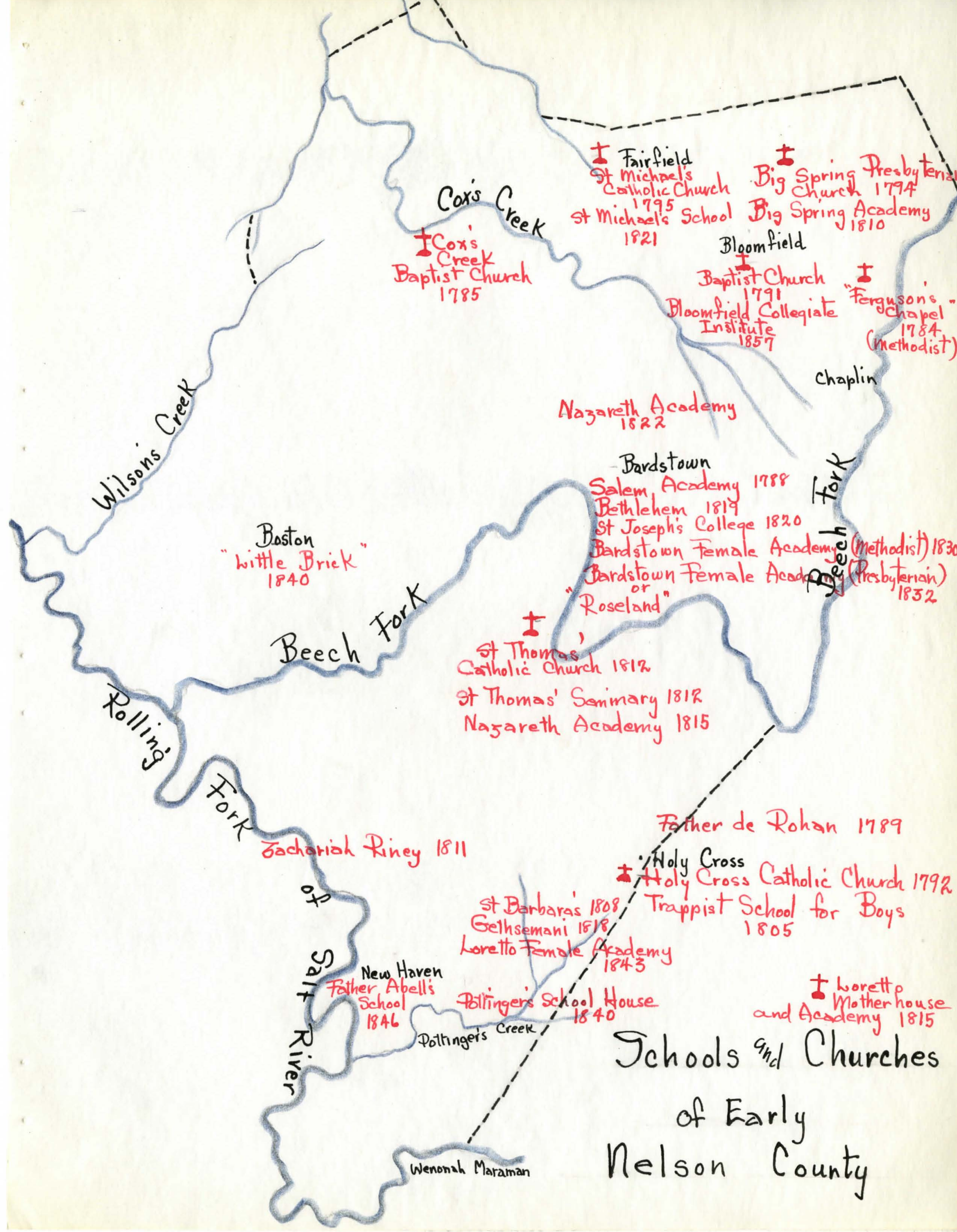


CHAPTER IV

The Influence of Various Religious Sects Upon Education in Nelson County

Most of the pioneer element demonstrated strong religious feeling and especially was this true of Nelson County. The new-comers settled in communities of like sentiment and early organized their churches and schools. The Baptists, Methodists, Presbyterians, and Catholies were the dominant religious groups of the county.

The Catholies

Back in Marylend, a group of Catholics who were finding that unsatisfactory oconomic and farming conditions offered little toward their future, dooided that the Kentucky frontier might present more to their children.

In 1785, a league of sixty families was formed, most of whom were from St. Mary's county. ${ }^{1}$ These families pledged themselves to emigrate to Kentucky and to settle together both for protection from the Indians and to establish, as soon as possible, a church and pastorate. In the year that the league was formed twenty-five families made the hazardous journey down the Ohio on flatboats to Iimestone, 2 then on foot orer

1. Ben J. Webb, The Centenary of Catholicity in Kentucky, p. 27 .

2. Limestone was the first name of the little settlement now known as Maysillo. 
to Harrodstown. They were in Kentucky by the spring of 1785. No doubt they rested awhile at the fort before they marched inland where thoy finally reached Goodin's Station, a few miles southwest of Bardstown.

Another group, led by Edward Howard, made the trip in 1787 and after landing at the falls of the Ohio, walked across country to Pottinger's Station. I This party was attacked by Indians while still on the river near the falls and lost some members of their group, one of whom was a Negro slave.2

It is beliered that Father Whelan, the first priest for the new colony, came with the Howard group. He was in Kentucky. where he attended to the spiritual need of these early Catholies, a little more than a year. 3

These Catholic families had been used to a fairly well established system of education back in Maryland. Assembly records of October, 1722, give a report of the treasurer showing that he had on hand quite a sum arising from the twenty shillings poll tax on negroes and "other taxables" to be devoted to the use of free schools of the various counties. In each county there were Grammar Schools located near the center of the county.4 Many, if not most, of the school teachers were clergymen of all denominations. Maryland had "home schools," neighborhood schools,

1. Camillus P. Maes, Life of Rev. Charles Nerinckx, p. 68 .

2. Ben J. Webb, op. cit., p. $\overline{68 .}$

3. Camillus P. Maes, op.cit., p. 70.

4. Matthew Page Andrews, History of Maryland: Province and State, p. 264 . 
private schools, denominational schools and free public schools.

Protestants of wealth sent their sons abroad or to William and

Mary College. Later many went to St. John's College at Annapolis.

The Maryland Catholias had suffered severe educational restriction during the era of persecution and only the wealthiest planters were able to send their ohildren to Europe to secure the advantages of a Catholic education. So far as is known no member of the group which went to Kentucky had been among the favored few, but practically all who went westward could read and write, and their early sacrifices to establish schools on the Kentuoky frontier show their appreciation of educational adrantages.l

These people hoped for much from the new land, not the

least of which was the promise of a better future for their

children. That future was to include educational opportunities

as well as financial and religious advantages. The extent of

their feeling is partly expressed in the following lotter.

You say you could wish yourself, at times, in this country, but the reflections on moving extrioate all notions of the kind. I must confess that it is a great undertaking but not as bad as you imagine. If you was to see the luxurious soil of Kentucky I think it would raise ambition in your mind that would surmount all dificulties of that kind, and as I think it would be for benefit of yourself and the children in particular. I could sincerely wish you were here and happily settled a near neighbor of mine. I have purchased six hundred acres of land that is good. I hed divided it in three Plantations, one for George, the other two for clem and myself. I begin now, though I have had exceeding bad luck in horses since I came to this country I have lost five valuable ones, to recover my settlinf in the woods, which has been one of the greatest diffioulties I have had to encounter with. I have 36 acres of land opened and in cultivation this year. I have next to

1. Sister Mary Ramona Mattingly, The Catholic Church on the Kentucky Frontier, 1785-1812, p. $\overline{14}$ 
build a house and then please God we have church. I hope to enjoy the fruits of the fertile land of Kentucky in peace and happiness the remainder of my days, with the additional blessing of having my children settled about me.l

By 1792 the second priest, Father de Rohan, had arrived, organized and ereoted the first Catholic Church in Kentucky.2 Holy Cross, in the Pottinger's Creok settlement neighborhood, was the name given to the new church.3 Father de Rohan was a teacher as well as a priest and later taught many schools in Nelson County. In 1797 Father Badin wrote of him,

Mr. Rohan keeps no more school on Salt River but his abilities are much thought of there.4

Father de Rohan also taught in Bardstown for a time but in 1798 went to live with Father Badin at St. Stephens where he taught in a cabin. He was still living in the Pottinger's Creok settlement as late as 1823 and was teaching a ochool in the village of New Hope.5 Finally he bought a farm in the neighborhood of Holy Cross where he made his home and no doubt continued to teroh.

Following the French Revolution a group of Trappist monks left France and sailed for America under the care of Father Urban in 1804. Father Urban had al ready visited Kentucky and had

1. Ibid., p. 9. Letter of Leonard Hamilton, an early emigrant, to his sister Elizaboth Hamilton McAtee, Hartford County, Maryland. Cited by Kelly and Cherault, Hamilton Family of Charles County, Maryland, p. 73.

2. Ben J. Webb, op.cit., p. 71.

3. Sister Mary R. Mattingly, op.cit., p. 42.

4. Ibid., p. 43 .

5. $\overline{B e n}$ J. Webb, op.cit., p. 71 . 
selected a site, on Pottinger's Creek about a mile from Holy

Cross for the new Trappist establishment. Here, in the wilder-

ness in the fall of 1805 the monks came.

On their arrival in Kentucky they opened a

gratuitous school for boys, whom they endeavoured

to train up in virtue and learning. This was the

first Catholic school of any note that was

established in our stato. It continued to

Ilourlsh for nearly three years. 1

The Trappists took in over twenty children from the

Catholic families of the noighborhood. They were free to learn

a trade or to take up the studies they had the most inolination

for? The school continued until 1809 when the Trappists again

moved, this time about forty miles away, over into Casey County.

The sohool, no doubt, was of value "but the monk's slight knowledge

of English was a great detriment." 3

In 1807, Rev. Charles Nerinckx, wrote to his parents in Belgium his intention of establishing a convent and school, as he felt catholic schools were greatly needed by the families of his district. The object of the convent was to provide, from the community, teachers for Catholic schools 4 The convent, Loretto, was begun in Marion County but just as the building was finished it burned to the ground and this first attempt at Catholio teacher-training was abandoned for some time.

1. M. J. Spalding, op.cit., p. 168.

2. Camillus P. Maes, op.cit., p. 109.

3. Sister Mary R. Mattingly, op. cit., p. 73

4. Camillus P. Maes, op.cit., p. 139. 
But the Archives of Loretto disclose the fact that a school was conducted by the Lorettines in Nelson County on Pottinger's Creok as early as 1808. It was called St. Barbara's and no information other than its date, 1808 to 1818 , is to be found. Later Father Nerinokx changed its name to Gethsemani. In March 1818, six sisters from Loretto moved to the Dent farm on Pottinger's Creek and opened a school for orphans. I This was evidently a continuation of St. Barbara's combined with the new orphan school under the new name of Gethsemani. If St. Barbara's school was in operation in $1808^{2}$ it was the first attempt at education for girls, other than subscription schools, in Nelson County.

Gethsemani continued its work for thirty years. The object was to provide eduoation for girls at low cost. The Prospectus of 1838 indicates the character of the institution.

Although there now exists in our state several flourishing and highly useful sohools and Academies for the education of young ladies, it must neverless be apparent to all that many parents and guardians are prevented by their ciroumstances from arailing themselves of those Institutions. Many indeed would prefer sending to an institution whose only object would be to afford means of acquiring a plain and competent education on the moderate terms. Considering this, and desirous of acoommodating all classes of their fellow citizen, the conductors of the Loretto Female Academy, have resolved to establish a preparatory school of this sort.

1. Ibid., p. 376 .

2. While the Loretto Archives testify as to the existence of St. Barbara's in 1808, Father Nerinckx's list of missions (cited in C. P. Maes, op.cit., p. 124), does not include this school. 
For this purpose they have selected Gothsemani, a beautiful, retired and hoalthy situation on Pottinger's Creok, about 12 miles from Bardstown.l

By 1843, The Loretto Female Acadeny was well established and excerpts from the Prospectus of that year are still more enlightening.

After four years experienoe the Conductors of Loretto finding that their Preparatory school of Gethsemani has succeeded beyond the most sanguine anticipation of its friends, that its patrons are well convinoed from actual experience of its great advantages, feel entire confidence that the merits of the institution are beginning already to bo known and appreciated by the public at large. Hence they have not hesitated to incure the expense of improvements, and they are now prepared to lodge and accommodate with comfort at least one hundred pupils.

The Community of Loretto will always furnish the sohool of Gethsemani with competent teachers and others to attend to every part of the institution and consult for the comfort as well as the improvement of its inmates. The pupils are assiduously trained to habits of order, economy, cleanliness and polite manners and hence they are always within reach of Maternal attention, whose kind and tender watchfulness secures their morals and elicits the willing observance of the rules. The sick are attended with maternal care and solicitude.

No uniform is required in the apparel but parents and guardians are requested to furnish comfortable and genteel clothing, as also to provide wash-pans, towels, soap, combs, etc.

The branches taught in this institution are as follows: Orthography, Reading, Writing, Arithmetic, English, Grammar, Goography and Plain Sewing. The pupils are also taught to cut and make their own clothes.

Terms - Boarding, Lodging and Tuition per session _ . . . . . . - $\$ 35.00$

1. The Catholic Adrocate, August 25, 1838 . 
The Louisville and Nashville mail stage passes within four miles of Gethsemani every other day, from which point conveyance may be had to the academy. 1

But in 1848, the erection of other schools making that of Gethsemani no longer a necessity, the farm was sold to another colony of monks from France. The price was five thousand dollars.2 The new order opened a school for boys. The Most Rev. M. J. Spalding writes of this school in 1851.

The fathers have already established a gratuitous sohool for the education of male children of any denomination, and there are now more than sixty children being taught therein reading, writing, arithmetic and English grammar. 3

The Sisters of Loretto established one other sohool in Nelson County. In 1821, a convent called Bethania, was opened near Fairfield and a school begun. The convent was closed in 1828 due to the failing health of most of the sisters but the school continued under the direction of the Lorettines, some of whom remained in charge of the parish of $\mathrm{St}$. Michael. This school continued from 1829 until 1838.4

Some of the handicapped children of Nelson County were indebted to the sisters of Loretto for the establishment of a Deaf and Dumb Institute? In 1840, three deaf mutes were taken under the direction of Sister Eulalia, the niece of Bishop Flaget.

1. Ibid., February 18, 1843 .

2. Anna C. Minogue, Loretto, Annuals of the Century, p. 52. 3.Ben J. Wobb, op.cit., p. 197 .

4. Anna C. Minogue, op.eit., p. 57.

5. Ibid., p. 97 . 
Sister Eulalia, head of the Deaf and Dumb School, had prepared herself for this work by study at "La Chartreuse pres" d" Auray," in Brittany. As late as 1843, the institute was advertised in the "Metropolitcan Catholic Almanac and Laity's Directory." The advertisement stated that the school was for girls who were deaf and dumb and that all branches taught in similar schools in the United States and France were being taught by the Lorettines. St. Thomas' Seminary was begun in 1812 about four miles from Bardstown in the Poplar Neck neighborhood. The land, 400 acres, was given by Thomas Howard, son of the Catholic pioneer who came from Maryland in about 1787.

May 22, 1811, Bishop Flaget and Father David with three or four young students went on board a flatboat at Pittsburgh to begin their journey to their new home in far-off Kentucky. On their arrival they found a little cabin used as a storehouse and another $\log$ building which was used as the home of the seminarians. Immediately they bogan a third building, also a log structure but of a better type than the other two, and by 1816 the following description was made by Bishop Rosati of St. Louis.

Father David had under his guidance twenty young ecclesiastics. They all resided together in a house constructed of logs, the crevices of which were filled with clay, which in drying, became as hard as stone. The upper part, roofed with rough boards, served as their common dormitory. 1

1. William J. Howlett, Historical Tribute to St. Thomas' Seminary, p. 36. 
The first student from Nelson County was in all probability, Robert A. Abell, son of a Catholic farmer of the community.1

No complete written record has been left but a few scattered remnants of writing make up the pictures of the early days of St. Thomas. The seminarians "made the bricks, prepared the mortar, cut the timber, etc. to build the church of St. Thomas, the Seminary and the Convent of Nazareth. Every day they devoted three hours to labor in the garden, in the flelds, or in the woods. One half to study, and half to labor was the rule of that day." 2

By 1817, there were fifteen students at St. Thomas, of whom five were studying theology. Only two were able to pay annually the sum of fifty dollars. Probably a part of this tuition of some of the pupils was paid in produce, as was the custom of thatday. Father David, the instructor of the students, was a man of culture. He had had years of teaching experience both in Europe and America before he began his work at St. Thomas. At the Sulpician Seminary at Angers, in France, he had spent four years. There he taught Philosophy, Theology and Holy Soripture. Driven to Amerioa by the Fronch Rovolution, he taught at Georgetown College for two years, then went to st. Mary's in Baltimore for five years. He was also a talented musician. Father David was fifty years of age when he began his work at St. Thomas. While a great part of the class work was under Father David's

1. Ibid., p. 26.

2. Ibid., p. 43 . 
supervision, especially the advanced work, some of the older

students assisted the younger pupils in their beginning classes.

In 1821 an assistant, Dr. Kenriok, was secured.1

The course of study at St. Thomes consisted of Theology, Scripture, Church Law, History and "knowledge of Church music suffered no drawback." 2 Father David recorded the routine observed by these first students,

The day extended from 4:30 a. m. to 10:00 p. m., meals being served at $7,30,1,00$ and 8,00 o'clock in the summer and half hour later in winter. The spiritual exercises began with a visit to the Blessed Sacrament, followed by morning prayers, meditation and Mass. At 10:00 0 'olock and at $12: 45$, and after dinner and after supper, visita were made to the Blessed Sacrament; at midday and erening there was examination of Conscience and at 4:00 the rosary. General recreation was engaged in from supper until night prayers. All the intervening periods were devoted to study, class and other work. From dinner until 4:00 the students engaged in manual labor. 3

But by 1818, it was deoided that the Seminary should be moved to Bardstown.

In the year 1818, Father David removed to Bardstown, with a portion of the seminarians of whom he was superior. Only those who were more advanced in their studies removed to Bardstown. The others remained at St. Thomas, which for some years continued to be a preparatory thoological seminary to which was annexed an elementary school.4

1. Ibid., p. 50 .

2. Ibid., p. 55 .

3. Sister Mary R. Mattingly, op.cit, , p. 212.

4. M. J. Spalding, op.cit., p. 242 . 
Bishop Flaget writes of the new school in 1820.

We have made a trial effort in opening a free school for poor Catholic boys who have not made the ir first communion. The half of their time will be employed in work on the farm, to defray the expense of their board, and the other half, in learning to read and write and being instructed in the catechism.l

The student body began to increase and the number reached twenty-five before the end of the year 1820, Bishop Flaget again wrote,

At present there are twelve students in the higher seminary, some studying logic, others thoology; and twenty-five in the preparatory courses at their humanities. We have not only to educete these poor children gratis, but we must furnish them with all the necessary books, etc., and board and olothe them. 2

This school flourished and soon some of the pupils began to pay a portion of their expense and tuition. Later thirty of them paid an annual sum of $\$ 35.00$, mostly in produce. 3

An unusual experiment was made at St. Thomes. As early as 1813 Bishop Flaget had decided upon a plan similar to that now followed by modern rocational or manual training schools. His idea was,

- - that perhaps, wo could unite together several artisans of different trades. Each might receive apprentices, and all who could work together in common without interfering with others might do so. The rest might work in a separate place, but always in the same enclosure. 4

1. William J. Howlett, op.cit., p. 72 .

2. Ibid., p. 72 .

3. Ibid., p. 76 .

4. Ibid., p. 77 . 
In 1826, ten young men were selected, Most of them were skilled in some trade and under their direction a new department was added to the school. A large new building was erected and training begun. But the combination of a teaching order and an industrial order was too great an undertaking as the sources of supply were not great enough to insure its success. For some reason, now unknown, the industrial Brothers left st. Thomas, in 1827, and removed to Casey County. Their removal was a severe blow to St. Thomas.

After the experiment in vocational training was discontinued St. Thomas continued as a college as well as a seminary. The collegiate department showed such growth and assumed such importance that in 1833 the following prospectus was issued.

St. Thomas' College

This House of Education, the first that was established by the Right Rev. Bishop of Bardstown, in the year 1811, is situated about four miles south of Bardstown, half a mile from the Nashrille Road, in a pleasant and healthy situation, and provided with extensive and commodious buildings.

The conductors of the Institution profess the Catholic religion, However, students of every denomination are admitted upon sole condition of conforming to the general rules of the house. This college, being considered as an appendage to St. Joseph's College in Bardstown, is conducted on 8 imilar principles. It is under the superintendence of the Right Rev. Bishop and his Coadjutor, who will occasionally examine the pupils and encourage their progress in the various branohes of literature.

The diet is plain but wholesome and abundant. The sick, if left in the house, are attended with the greatest punctuality and tender care without expense to the parents except for medicine and the physicians attendance. 
In this college are taught, Reading, Writing and Arithmetic, English Grammar, Geography with the use of maps and Globes; Book-keeping, Surveying and the most essential branches of Mathematics, the Latin, Greok and French Languages .

\section{Terms}

Board, including washing and mending, with the tuition of the three branches first specified ........ \$72.00 specie Tuition of the other branches . \$16.00

None are received as boarders unless they pay their first quarter in advance, and a want of punctuality in paying the other quarter in advance will create the painful necessity of sending back the pupils to their parents or guardians, experience having proved that a contrary practice is ruinous to the Institution.

The boarders will find themselves in bed and bedding, hand towels, a silver or tin goblet, decent clothing, books and stationary. A charge of $\$ 4.00$ for bed and bodding, and $\$ 3.00$ for stationary per annum will be made when furnished by the Institution. 1

But as a college, St. Thomas did not continue long.

In 1836, it was again decided to make it over into a preparatory seminary. The last class received was removed from St. Thomas into Bardstown in October, 1869.

In connection with st. Thomas an interesting bit of information is brought to light through an inquiry purporting to have been from Henry Clay, Secretary of State of the United States Government. This letter, later found to be a forgery, was received by Bishop Flaget in 1825, and requested the educational statistics of the Diocese. In reply, Bishop Flaget sent the following summary account of the various establishments in Nels on County.

1. Ibid., p. 91 . 
1. Diocesan Seminary at BardstownNineteen seminarians, who also teach in the college - cost of the building $\$ 6,000$

2. Preparatory Seminary at St. ThomasFifteen young men, two priest and five teachers. To this is annexed a school for boys, with thirty students, who pay annually $\$ 35$ in federal money, mostly in produce - cost of the buildings at St. Thomas - $\$ 11,400$

3. St. Joseph's College - Will cost $\$ 20,000$ when completed.

4. Sisterhood of Nazareth - Sixty Sisters, sixty boarders in Nazareth academy - school of Nazareth becoming popular and patronized throughout the whole Western Country. 1

Nazareth Academy did become one of the outstanding girls' schools in the south. It also had its beginning on the Howard land, the same site that was home for St. Thomas' Seminary •

In 1812 two women, Sister Teresa Carico and Miss Elizabeth Wells made their home in one of the log cabins close to the church of st. Thomas. They were the first sisters of the new order, The Society of Sisters of Charity of Nazareth, in Kentucky. 2 Their work, at first, consisted of the manufacture of clothing for the inmates of st. Thomas. But in 1815 the seminariens erected another cabin for the sisters and in this was started girls' school. From its beginning the school was a boarding institution but had a fow days pupils. The sisters themselves were not trained for teaching but receired instruction from their founder, Father David, in the various branches they planned to teach.

1. M. J. Spalding, Life of Bishop Flaget, p. 302 .

2. M. J. Spalding, Sketches of Early Catholic Missions of Kentucky, p. 230. 
The first student received was Cecilia O'Brien.l This littlo girl, a noighborhood child, was entered as a day pupil, but owing to the distances between their homes and Nazareth there were few such pupils.

From August, its opening date, to December the school enrollment was nine. A year later the sohool had grown to thirty-four. Considering the difficulties of going to and from sohool, the sparsely settled country and the lack of means of those pioneer days, the attendance record was good. For some time the sisters had been saving for a new building, a briok one, as it had been decided to erect no more frame buildings. In 1818, a brick building was finished, large enough to accommodate fifty boarders and at the same time two smaller houses, one brick and one of stone were added to the establishment. This was indeed unusual as few structures of the kind existed in the neighborhood.

With Nazareth growing rapidly, it was a shook for the sisters to learn that the ground on which the school and motherhouse stood did not belong to them and never could. The will of Mr. Howard precluded the possibility of the land being sold even to a religious order.2

When this condition was found the sisters immediately selected and bought a new home site. North of Bardstown lived p. 24 .

1. Anna Blanche McGill, Sisters of Charity of Nazareth, 2. Ibid., p. 32 . 
Mr. Lapsley, a Presbyterian minister. In 1822 his land was purchased and the more from St. Thomas was made. After the change the inconvenience of mingling day pupils and boarders made it desirable to discontinue the taking of day students and only boarding students were receired.

By 1824, the community at Nazareth numbered twenty-eight sisters, many of whom were teachers, about thirty boarding pupils eight orphans and three servants.1

Ny first remembrance of Nazareth as it appeared to mo as a small child in 1825-26, is a plain frame farm house in a verdant, spacious yard filled with grand forest trees. An ample orchard was the daily temptation of the children. The girls arose long before daylight in the winter, and by the dim light of tallow candles, in tin scones, huddled down the stairs. On benches in the school room or gallery, they broke the ice to get water from the tubs which held it. In summer their faces were often washed at the spring, or, what was sweeter still, they were bathed on the way in the dews from the grass, for wo believed that would make us fair. 2

Such were some of the memories of that period held by one of Nazareth's former pupils.

The first accounts, compiled from the memories of early students and teachers, emphasize the courses in Christian Doctrine, grammar, writing, music, history, French, plain sewing, tapestry and embroidery. The regular school work was supplemented by lectures from the professors of St. Joseph's College, in Bardstown, on philosophy, chemistry and literature.

1. Ibid., p. 33 .

2. Ibid., p. 117. Mrs. Eliza Crozier Wilkerson's recolleotions of early Nazareth. 
An interesting letter written by a pupil of Nazareth in

1828 is preserved at The Filson Club.

Nazareth may the 28th, 1828

My Dear Sister,

I feel quite dissapointed that you have never written to me since I have been here. I have been here a month and have not received a line from you. I have been tolerably well since I left home. I could not write sooner or I assuredly would have done so; we are allow'd to write every other weok \& last week I went to Mr. Rowan's \& could not write. I scarcely know whether I learn fast or not but, I hope I do. The branches I study are Geography, Grammar, Arithmetic, Music, Drawing, and Needlework. I love Mother Katherine and the sisters very much, Sister Ellen, Sister Marcelina \& Sister Clotildas, in particular. If you wish to know more about the place write to Aunt W-, She will tell you. I have not time. I shall only try to describe a ceremony that was performed last Thursday. It is called the procession, a rite of the catholic Church, with which I am unacquainted. About 50 girls from here dress'd in white with white vails, and ribbons, pink shawls and wreaths on their heads. These walk'd by couples about 2 yards apart. Miss Naneon Tarasoon walk'd at the head of the Column \& carried a satin banner superbly painted. The Sisters followed after the girls. Then a gentleman in black carried another Banner, and after him the College boys dress'd very elegantly in pink satin frocks with lace ones orer them and carrying a basket of flowers cover'd with satin. In the center of the procession 4 boys carried a kind of table cover'd with satin \& on it a large urn of incense burning. Immediately after that 4 clergymen carried a canopy under which the Bishop and his bishop coadjutor walk'd. The procession proceeded a quarter of a mile to a gradual emminence thro Howards beautiful woods, adjoining st. Thomas 3 miles from Bardstown. There was a splendid recess form'd in a beautiful enclosure. There were seats prepared for the whole company. A small sprinkling took place \& forced us to return to the house so that the 
sermon was not preached there as at first intended. Aunt \& Uncle W- came down last week, and took me to Mr. Rowan's. Miss Ann and Josephine are coming up with me in August and I promis'd that you should be there to receive us. Present my love and duty to mama \& brothers \& all my friends. An now farewell dearest, best lov'd, family Fare thee well porhaps forever If forever fare thee well Let my Condness for me never In thy bosom's coase to dwell Marianna Barkley

P.S. There were thousands of spectators at the procession tho very good order was kept.1

Another pupil's recollections depiot the school's growth.

In my sohool days French was taught by French ladies, Madame Boyer and Mademoiselles Tatu and Dafour. Mesdemes Blaque and chase drilled the girls in grace and deportment. And professors taught dancing. Monsier de Grandeville demonstrated this art by doing all the dancing himself - or more accurately, gyrating - scolding profanely in French when the girls failed to skip and wirl as nimbly as he did. His fiddle and bow received rough treatment in consequenoe of his impatience.

In 1856 the uniform, long characteristic of Nazareth pupils was adopted. Garbed in purple calicoes on week days, and in buff dresses on Sundays, varied by maroon and blue winter frocks, capped by a nondescript but unique Quaker scoop, a Nazareth girl was easily identified. Lessons and tasks did not monopolize all our time. The Sisters allowed us to play, dance and sing as wo pleased. Our stage performences were amusing. Musical soirees, concerts, serenades, and minstrelsy from the Bardstown swains kept our spirits attuned to youthful gladness. There were picknicks, lawn parties, candy pullings, hay-rides, phantom parties, nutting parties and fancy balls with Nazareth colored band to fiddle and pick the banjo.2

Although diplomes were not conferred until 1858, prizes, premiums and medals were distributed much earlier. In 1843

1. The Filson Club. Letter from Miss Marianna Barkley to her sister Miss H. Barkley.

2. Anna B. McGill, op.cit., p.125. 
the following program was given at the commencement and examination.1 That year there were ten young lady graduates, each of whom prepared and read a paper. The titles of these were,

1. Iceland

2. Chivalry and the Crusades

3. Imagination

4. The Power of Consoience

5. History

6. Wealth, and its Effects Upon Individuals and Society

7. Knowledge is Power

8. Commerce

9. The Beauty of the Physical, Moral and Intellectual World

10. Sublimity of American Scenery, and its Influence on National Character

At the same exercises the prizes and medals were awarded.

Prizes

Superior Literature and Merit

Medals

Conduct and Diligence

Premiums

Composition

Botany

Chemistry

Moral Philosophy

Montal Philosophy

Natural Philosophy

History

Rhetoric

French

Mus io

Piano, Guitar, Harp

painting in Water colors

Mezzotinto

Writing

Grammar

Geography

Arithmetic

Reading

Orthography

Embroidery

Needlework

Tapestry

Plain Sewing

1. Catholic Adrocate, August 5, 1843 . 
Such an array of awards indicates the scope of the curriculum and the typo of institution, ovidently a finishing school, that Nazareth had become just prior to the civil War period.

In 1819, three sisters from Nazareth oame to Bardstown from the motherhouse at St. Thomas and began a day school for girls. The new establishment was called Bethlehem and was opened in a house which had previously been seoured by Father David. This school continued for many years.l

About the year 1820 Bishop Flaget selected Rev. George A. Elder to organize a school for boys. 2 It was opened to day scholars in the basement of the theological seminary. It remained there for about a year. The seminary students assisted Rev. Elder with the duties of the sohool. The attendance was good and increased rapidly. The President then decided to erect a separate building for the new institution which was to be called st. Joseph's College.

The first wing of the new building wes paid for from the procoeds of the day-pupils. It was then decided to include boarding students and soon the building was overflowing.

In 1823, the north wing was built, and soon afterwards the front building, connecting the two wings, altogether forming one of the largest and best appointed school structure then to be found in the entire western country.

1. M. J. Spalding, Sketches of Early Catholic Miss ions in Kentucky, p. 234.

2. Ibid., p. 279.

3. $\overline{B \theta n}$ J. Wobb, ㅇ․ㅅt., p. 278. 
In May 1825, the student body was greatly increased by the addition of fifty-four young men brought up from the South. A southern college, for some unknown reason, was disbanded and part of its students transferred to St. Joseph's. This was the beginning of that southern patronage which was destined to render the institution 80 flourishing in after days; and also, on the subsequent heary pecuniary derangement of the South.1

A disastrous fire burned the main college building to the ground in 1838. Its president, Rev. Elder, died soon after. of course the loss had a serious effect upon the prosperity of the institution. The erection of new buildings incurred dobt. Rev. M. J. Spalding succeeded Rov. Elder and was followed in turn by Rers. James Lancaster and Edward MoMahon.

But after a struggle the college regained its old standing and in 1847 had a student body of 150, with a faculty of four professors, in addition to the president. Its library numbered 5,000 volumes.2 When Father MoMahon's administration ended in 1848 about 6,000 young men, coming from noarly all the states in the south and west, had spent at least a year in study at St. Joseph's. 3 St. Joseph's also held annual examinations to which the public was invited. But by 1860 commencement exercises were held. The commencement began with a march of the cadets through the town, followed by selections given by the college Band. The following

1. M. J. Spalding, Sketehes of Early Catholio Missions in Kentucky, p. 279 . 2. Alvin F. Lewis, op.cit., p. 320. 3. Ibid., p. 320 . 
are the graduates, their addresses and comments.

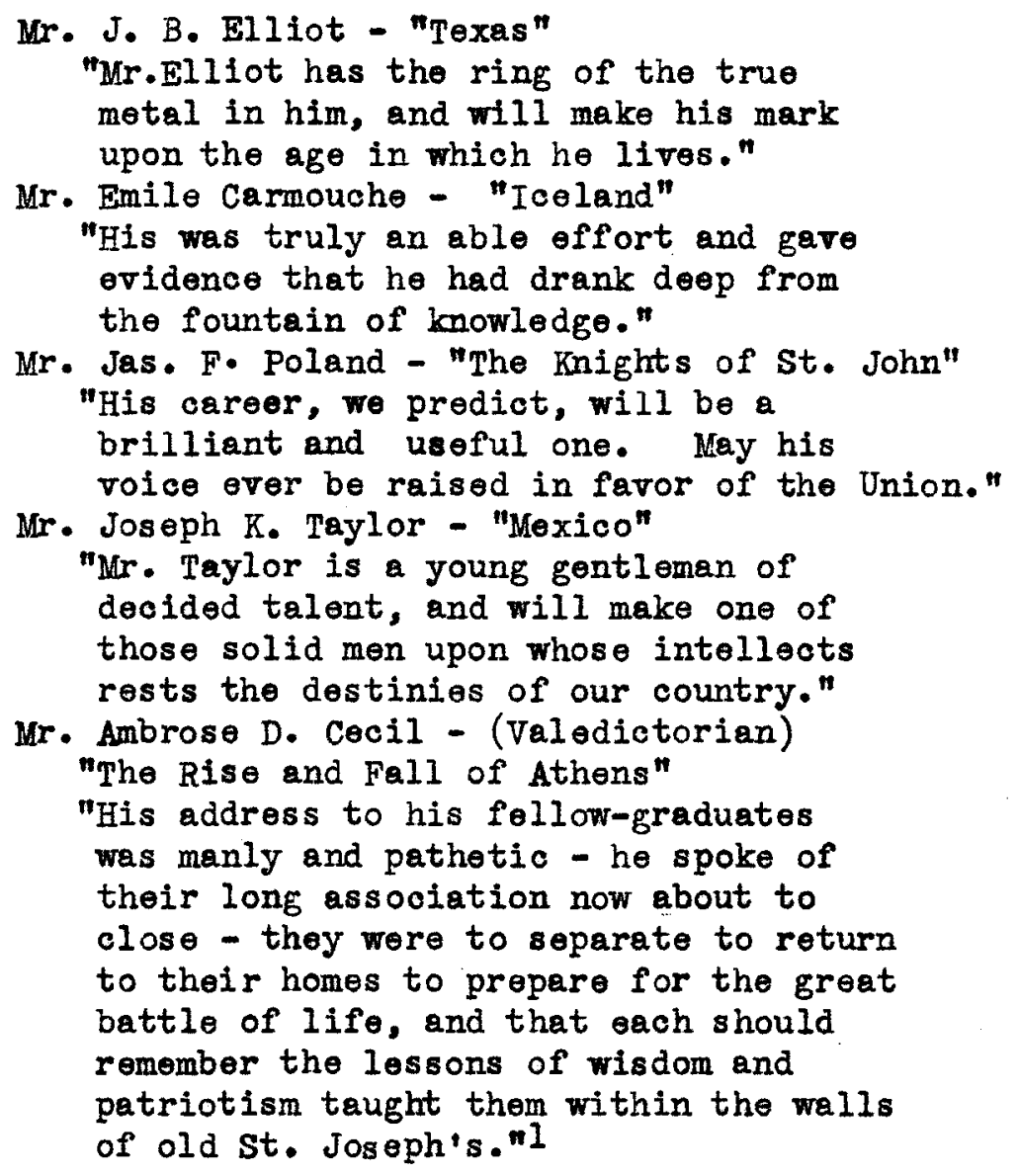

In the New Haren district there was a parochial school

for boys. This letter tells something about it.

You requested me to tell you what school I attended in New Haven with Robert L. Pottinger's sons.

It was a sohool started by Fathor Abell and taught by Father Rogers in 1846. I left St. Joseph's College, Bardstown, when my mother died in 1845; was not well up in Arithmetic and that was my main study with Father Rogers in 1846. I wanted to quit that sohool and go in the lexican War in 1846, but my father and Father Abell persuaded me from going. 2

1. Saturday Gazette, July 7, 1860.

2. Samuel Forest Pottinger Manuscript Collection of Nelson County History, Letter from J. M. Bucloman. 
The Catholic schools supplied a great educational need in Nelson County. They wore established early and when the state provision for county academies was failing and before the public school systen began to function, these catholic institutions filled the gap. Especially did Nazareth and Loretto do much for girls who would otherwise have been unprovided for.

\section{The Methodists}

The Methodist influence, while not as obvious as the Catholic, was in many respocts equally as far roaching. Frontier Methodism had a very large social and educational, as well as religious, influence. The autumn camp meetings were the places of extensive mingling. Practically every circuit planned such gatherings, when people from far and near came, lived in huts; wagons and tents and spent much of their time in social intercourse.l

At such times the pioneer families listened to eloquent speakers, men of education and background, who no doubt, instilled desires for learning in many hearers. Not all of the Methodist preachers were educated men, but those with little schooling recognized its value and were deeply interested in bettering educational conditions.

The circuit preacher resolutely carried books to the people and in most cases actually forced them upon the settler.

Many a frontier cabin would have been without a single book if some circuit rider had not insisted

1. William Warren Sweet, Rise of Methodism in the West, The Journal of the Western Conferenes, 1800-1811, p. 67 . 
that books be purchased. This was part of the preacher's duty, and most of the preachers were faithful in its performance. The books were read in the household, then were loaned to the neighbors until they made the circuit of the settlement. 1

The Methodists felt so strongly upon the subject of book distribution that the General conference of 1800 passed this rule.

It shall be the duty of every preacher who has charge of a circuit to ses that his oircuit be duly supplied with books which are sent to him, from time to time, or which may be in his circuit. 2

of course, these books were largely publications of the

Methodist Book Concern, but they were books on a variety of subjects. Many were biography, travel, history, philosophy and ethics while the rest were of a religious nature, the works of Methodist writers, Wesley, Fletcher, Clarike and Lee.

At the General Conference held in Baltimore, October 20, 1796 , several measures were adopted which affected the establishnent of Methodist schools in Kentucky. The Conference drafted a measure which set forth the purpose of such schools and proposed a set of rules for their management. 3

- . our particular desire, that all who shall be educated in Methodist seminaries, be kept at the utmost distance as from vice in general, so in particular from softness and effeminacy of manners.4

1. Ibid., p. 68 .

2. Tbid., p. 69.

3. Rev. W. E. Arnold, A History of Methodism, Vol. 1, p. 145.

4. Bethel Seminary, 1798, Kentucky's first Mothodist sohool, was situated out in the country away from town which was supposed to be a hot-bed of evil. 
Early rising was enjoined as a means of preserving health of body and developing the mind. No play of any nature was allowed.

- . the students shall be indulged with nothing which the world calls PLAY. Let this rule be observed with the strictest nicety: for those who play when they are young, will play when they are old.1

A schedule was prepared for the students as follows: Rising at five o'clock Public prayers at six Breakfast at seven study from eight to twelve Recreation and dining from twelve to three study from throe to six Supper at $s$ ix Public prayers at seven Recreation until bed-time and all in bed at nino o'clock, without feil.

The recreation listed as being suitable, "gardening, walking, roading and bathing, without doors; and the carpenter's, joiners, cabinet-makers or turner's business, within doors." The rule for bathing was "that a master, or some proper person by him appointed, shall be always present, only one shall bathe at a time; and no one shall remain in the water above a minute." 2 As authority for the correctness of this set of rules for governing a seminary or school, both Locke and Rousseau are quoted.

At a still later conference in 1832 the question of education again occupied an important place. 3 The Bardstown

1. Rev. W. E. Arnold, op.cit., p. 145.

2. Ibid., p. 145 .

3. A. H. Redford, Western Cavaliers, p. 27. 
Female Academy, with William M. MeReynolds, Superintendent, received special attention along with Augusta College and Science Hill Female Academy at Shelbyville.

Nelson County was farored by the presence of several of the most cultured and best educated men among the Methodist leaders during her early frontier period. Bishop Asbury visited Colonel Hardin's family on his way to the Kentucky Conference in 1792.1

Endowed by nature with a clear, strong mind, thoughtful and studious, he made himself a ripe scholar reading with oase the Latin, Greek and Hobrew. He was truly eloquent and his sermons were logical, systematicaly arranged, and delivered with great power.2

Such a man, thrown in contact with such a family, one which already had aspirations for education, must have exerted a great influenoe upon them and their neighbors.

Wilson Lee was frequently in Nelson County in the Chaplin district. This vieinity wes the stronghold of Methodism. Here the Methodists had a well organized churoh known as "Ferguson's Chapel" as early as 1784.3 Lee was only twenty-six years old when he arrired in Kentucky but his early advantages were of a superior character. He came from a family of refinement and wealth. His manners were polished and he was an able speaker. Another Methodist who must have influenced various communties in Nelson was Henry Birchett. He was talented, popular Vol. 1, p. 119.

1. A. H. Redford, The History of Methodism in Kentucky, 2. W. E. Arnold, op.cit., Yol. 1, p. 73 .

3. A. H. Redford, The History of Methodism in Kentuoky, Vol. 1, p. 35. 
and especially successful with children. In every neighborhood he visited he took keen interest in them, formed classes and himself taught thom.l

But much credit for influence should be given to those unnamed preachers who travelled around the countryside living in the homes of the people of their faith. Entirely aside from the religious influenoes which emanated from such oontacts was his example as a studious person. The books he brought into the $l 0 g$ cabins, the conversations carried on at the table and around the fireplace and surely the reading from the Biblewithout a doubt all of these were fruitful sources for enlightening both the adult and younger members of the family.

The Methodists opened The Bardstown Female Academy in 1830.

The Bardstown Female Academy, 1831

The second session of this institution

under the superintendence of Mrs. MoReynolds, commenoes on Monday, the 1lth of April. Terms of Tuition.

orthography, reading and writing per session of 5 mo. -.......... \$6.00

English, Gramar, Geography, with the use of Globes, Arithmetic and History, including the abore, Drawing and Painting Maps -

Moral and Natural Philosophy, including Astronomy and Optics, Rhetoric, Logic, Composition, etc. - ......... \$12.00 Ornamental needlework (extra) - $\$ 4.00$ Music on the piano (extra) - $\$ 16.00$ No pupil will be received for a shorter term than five months.2

1. Ibid., p. 73 .

2. The Western Herald, March 30, 1831. 
The next year the following announcement appeared in the

looal news paper.

Mr. McReynolds has lately procured a large and convenient building where he will be prepared to accomodate any number of Boarders that may apply.

Board per session -.... \$35.00.1

This school continued for many years but was finally purchased by the Baptists who renamed it "The Bardstown Institute." 2 Some years prior to the Civil War the sohool was under the direction of Dr. Atkinson, Baptist minister. ${ }^{3}$

\section{The Presbyterians.}

The Presbyterians located early in Nelson County. This was perhaps the leading faith in Bardstown soon after its establishment as a township. While out beyond Bloomfield was the Big Spring community whose church was erected in 1794.

It was the custom of this faith for the teacher of their parochial schools to be minister. Sometimes he was pastor of the church as well as school teacher but frequently he was not. peaching for the time being had become his vocation. One of the earliest of these minister-teachers of which there is a record in Nelson County was the Reverend Joshue Lacey Wilson. He was

1. Ibid., March 24, 1832 .

2. This building on South Third is now occupied by Mrs. John A. Newman while the one on North Third which housed the Bardstown Female Academy (Presbyterian) is now the home of Mrs. James B. Beam.

3. Interview with Mr. Ben Johnson and Miss Ella Kourenbergh. Miss Kourenbergh's mother, $\mathrm{Mr}$. Johnson's mother-in-law, attended this school some years before the war. Dr. Atkinson was then its hoad. 
ordained pastor of the Big Spring Church in 1804 and at the same time taught a school in Bardstown. 1

Occasionally the teachers were men who had been licensed to preach, but not yet ordained. At least they were men described as "college students" though the length of their preparation was uncertain.

In the Presbyterian parochial schools the discipline was strict but mild. Corporal punishment was used, but not frequently. 2 "Exhibitions" and "Public examinations" were the custom and took place at the end of the year. At these programs the student had an opportunity to make a public appearance in recitations, reading of essays, giving musical numbers or debates. But there were those who felt that for girls to do these things would cause "a sad deterioration of the female character, fostering vanity, extravagance of dress and love of display." 3

The public examination, advertised so often in the Nelson County newspapers, was conducted carefully, the examiner usually being some outsider, a person not connected with the school. They occupied a whole day, and not infrequently two days. The parents and visitors made it a social occasion; while at times the session of the Church attended. These examinations gare evidence to the community of what had been going on in the school and was a test of the teachers as well as pupils.

1. Robert Davidson, History of the Presbyterian Church in the State of Kentucky, p. 364 . 2. Lewis Joseph Sherill, Presbyterian Parochial schools $1842-1870$, p. 124 . 3. Ibid., p. 117. 
The Presbyterians believed strongly in Sabbath Schools.

Ministers have peouliar facilities for the promotion of Sabbath Sohools. They are generally iiterary men, and therefore may be supposed to be acquainted with the different improvements in popular education.1

Each Sabbath Sohool was the source of books, for they all tried to maintain a library. These libraries were, in a considerable degree, composed of biography and historles, with Sabbath School periodicals.

The Presbyterian view towards education is expressed in the Prospectus of a publication issued by them.

Prospectus of

The Transylvanian or

Lexington Literary Journal

To diffuse more widely interesting and useful knowledge; to record the progress and invention. in the arts; to mark improvements in the science and art of teaching; to advance the science and interests of education in all its departments and to promote a pure and elevated morality are the objects of "The Transylranian." This work relies for patronage on those who have tasted the pleasure of knowledge, and whose patriotism prompts them to labor for its diffusion. Judicious efforts to increase the intelligence in this Western country, which is soon to exert an important influence on the destiny of the whole union.2

Nelson County was fortunate in that to Bardstown came a Presbyterian minister and educator whose educational influence was to be felt by the whole community. The Bardstown Female Academy (not to be confused with The Bardstown Female Institute,

1. Western Luminary, March 11, 1829.

2. Ibid., January 14, 1829. 
Baptist school) was started in 1832 by Dr. Nathan L. Rice, D.D. Dr. Rice came to Bardstown from Danville where he had studied and taught at Centre College. He immediately saw that many Protestants were educating their children in the Catholic institutions in the vicinity. To counteract this influence he established the girl's school, the first protestant female institution under ecclesiastical control in the West. 1 Dr. Rice was vigorous in his assertion that it was as important to found permanent femalo colleges as colleges for males.

He was ordained in 1833 and became partor of the church as well as head of the new academy. Soon afterward he became involved in a controversy with the catholics relative to the case of an escaped nun, Milly McPherson, who charged a presiding priest of a nunnery near Lebanon, with immoral conduct. The Catholic element began publishing a woekly paper called "The catholic Advocate." Dr. Rice, though without means, immediately began the publication of "The Western Protestant," thus making himself editor, minister and teacher.

The two papers carried on the controversy. The case became famous and involved Dr. Rice in a lawsuit which produced great excitement throughout the country.

But Dr. Rice proceeded with the school and one of the oarly announcements is found in the newspeper.

1. Lewis Collins, op.cit., Vol. I, p. 481 . 
Bardstown Female Academy

The various branches of female education will be taught as heretofore.

The boarding department will be attended

by Mr. Wm. Bard and Lady. The Principal and

his family will board with Mr. Bard.

$$
\text { N. L. Ricol }
$$

A new department, The Bardstown Collegiste Institute, had evidently been added for the same advertisement carried some additional information - not only would the school teach the regular subjects but "Hebrew Language and French taught by a French gentleman." And at the end was this requirement.

Each pupil will be required to have a desk, with lock and key, in which he can keep his books safely and neatly. ${ }^{2}$

Dr. Rice remained in Bardstown until 1847. He became widely known through his work in Bardstown and in 1874, after preaching for several years in New York City, he was made president of Westminister college at Fulton, Missouri.3

Dr. Rice's successor as minister and head of the Bardstown Presbyterian Church and academy was Rev. Jouett Vernon Cosby, a native of Virginia. He was educated at Hampden-Sidney College, Union Seminary, Virginia and at Princeton, New Jersey. He read a thorough course of law but abandoned it for theology.

Dr. Cosby was a writer also, and one poem of considerable length, "Consecration" was published in pamphlet form in 1874.4

1. Bardstown Herald, Wednesday, March 30, 1836.

2. Ibid., March 30, 1836.

3. Lewis collins, op.cit., Vol. I, p. 480.

4. Ibid., Vol. I, p. 607 . 
A circular of The Bardstown Female Academy in 1856 reads

The next Session of this Institution will open, as usual, on the First Monday of September, and continue through two consecutive terms of Twentytwo Weeks each.

The Course of Instruction is liberal and thorough; the Teachers in the several Departments are of the first character; the Discipline is as Home-like as it can be made; and the accommodations, in respect to Rooms, Board etc., are extensive and good. We feel justified while we once more earnestly invite the attention and solicit the patronage of those who desire to afford their daughters an accomplished education, on the principals and conducted according to the liberal scele of Protestantism.

Charges - Term of Five Months Regular Course

Primary Department .................. \$8.00

Section lst $\ldots \ldots \ldots \ldots \ldots \ldots \ldots \ldots \ldots 12.00$

Junior Section 2nd .............. 16.00

Senior Section lst .................\$16.00

Section 2nd ............... 18.00

Extra Course

Instruction on Harp, with use of

instrument $\ldots \ldots \ldots \$ 30.00$

do on Piano do ..............\$20.00

do on Guitar do ................\$14.00

Drawing, plain and colored, crayon ......\$12.00

Painting, water colors and oils ........ \$15.00

French, Latin or Greek, each .........\$10.00

Board in Institution, including Washing, Lights, Fuel in Bed-Rooms, $\$ 2.00$ per woek.

Charge for use of Books in the Academy Library

and use of Chomicals and Philosophical apparatus not to exceed $\$ 3.00$ per Term. These at the option

of Patrons.

Bardstown is remarkable for its healthfulness. It is easy access by good turnpike roads from Louisville, Nashville, Harrodsburg ote., and having a Telegraph office, ready communication may be had between the pupils and patrons of the Academy.

Communications addressed to the Prinoipal or to any member of the Board of Trustees, will receive prompt attention. J. V. Coaby, Principal 
Trustees - Charles Norse, J. Wood Wilson,

T. P. Linthicum, Joseph Brown, Hon. C. A. Wickliffe,

Wim. Sutherland, Jacob Rizer, Thomes S. Speed, James M. Doom.1

Dr. Cosby was especially interested in Astronomy, Botany

and Geology.2 He had on excellent planetarium and telescopes

along with a large, well catalogued rock collection.

Mrs. Cosby taught both piano and harp but the head of the

Music Department was Professor Hast.

Louis Hast obtained his primary education in the sohools of Gachlingen, Bavaria, studied Latin and the sciences in the noted old town of Landau and then went to Munich, where he deroted eight years to the study of music and graduated from the famous Conservatory of Music in that city. He came to America soon after the German Revolution of 1848 and in 1849 accompanied by his younger brother, who was a promising artist, came to Kentucky. They both went to Bardstown, where Louis H. Hast became connected with Mr. Cosby's noted school as a teacher of music. 3

Professor Hast left Bardstown for Louisville after 1854. His musical talent and superior ability as a teacher made him quickly recognized and his great work established a standard of musical culture which placed him as the leader in his field.

Dr. and Mrs. Cosby renamed the academy "Roseland," but the school was equally well known by both nemes. Dr. Cosby left Bardstown for the four years of the Civil War, and was head of Rose Hill in Versailles, Kentucky. After the war he returned to

1. Bardstown Herald, October 28, 1852 .

2. Interview with Mrs. Carrie Fulton, daughter of Dr. Cosby.

3. J. Stoddard Johnston, Memorial History of Louisville, Vol. 2, p. 519. 
Bardstown and remained until his death in 1877. The sohool was continued, under the direction of his widow, until 1881, having a life span of fifty years as one of the truly prominent schools of the state.

The closing exercises of the academy in the year 1860 describe, better than any other words, the type of work and the feeling of the citizens for this institution which played a major role in the educational system of Nelson County.

The closing exercises of the Bardstown Female Academy occurred on Wednesday, the 12th ultimo. It is our pleasure, through your courtesy, Editor, to bear testimony to the high qualifications of Mr. Cosby and his corps of teachers, as educators; and we can do so no more definitely than to call attention to the proficiency of the young ladies in their studies. The examinations of the Senior Class, occupying Thursday and Friday of the preceding weok, and conducted by the principel before the Board of Truatees, was rigid, comprehensive and more than satisfactory. On Monday and Tuesday, the Teachers of the Primary and Junior Departments certainly must have realized great pleasure in seoing the complete success which crowned their labors. Every class promptly responded to the questions, which were asked at random through the text-books. The music, selected in classical taste by the accomplished teachers, gave every lover of the heavenly soience who heard it the highest pleasure. The compositions read were beautiful - just like the fair readers, lovely in expression, and a combination of pure ingenious truths. The young ladies in the French and Latin classes gave clear indication as to what ladies can do in languagesd The exhibition on Wednesday was the reflex of $\mathrm{Mr}$. Cosby's system of Education. Every thing savoured of that grace and gentle dignity which eminent christian scholarship only can give. It is only these occasions that the unusuel labor in the leoture room laboratory clearly announces its reward. Cultured originality was the peculiar beauty of each composition on that 
day. The dull and wornout phrases of the textbooks gave place to the ready suggestions of minds beautiful in their own imagery and powerful in tutored strength.

The first composition - subject - "Homeward Bound," by Miss Nichols, formerly of Danville, Ky., now of Missouri, was at once a statement and lovely illustration of Woman's destiny, or as she expressed it, "Homeward Bound and Home Abiding - this is our

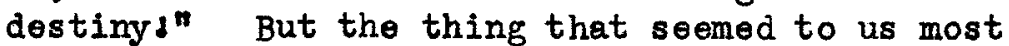
pleasing was the tender pathos with which she bade farewell to her Kentucky home, as it had been, and her graceful, womenly welcome to her western home, which was to be.

Miss Powell, of Virginia, gave us her views about the "Pre-eminence of Morel Worth." We are sure her composition was characteristic. It was a meek but heroic statement of moral beauty - above all was that the world calls great or good. And we can wish to her no higher boon, or one more consonant with her character than that in the walks of life she may be permitted to exemplify her ideal.

"Me, and Not Me," by Miss Bagly, of Norfolk City, was a scholarly resume of the constitution and relations of man.

Miss Corbell, of Virginia, entertained us with the facts of "Moonlight Hours in Jupiter," and if these facts are as her fine imagination pictured them to be, on that fine planet we would like to go with her there, the next time she visits it; and would be better pleased to make it our place of abiding if - well, if -. We have seldom heard facts of soience more pleasingly interwoven amidst the fine playthings of fancy.

Miss Hite, of Kentucky, discouraed fluently and nobly on, "Woman's World." It was the social apotheosis of Woman. Her destiny, she said, is to plaoe the crown of sooilal regeneration upon the brow of man. And as she uttered chivalrous thoughts upon the subject we quietly but very deeply felt an entire willingness to go on to such a destiny under suoh a leader.

Miss Forman, of Kentucky, presented the Bouquets to the graduates, and to Mrs. Cosby on behalf of the young ladies of the Primary and Junior Departments, in a very sweet and pretty speech. 
Miss Phillips, of Virginia, was honored Valedictorian of her class. Circumstances forbade us the pleasure of hearing her, but we have heard many compliments bestowed upon the manner in which she delivered the farewell address.

After conferring of Diplomas and Presentation

of Bibles to the Graduating Class by the Prineipal, the audience was dismissed with, to them the unwelcome announcement that $\mathrm{Mr}$. Cosby would, on the 2nd Monday in September next, open the next session of the "Rose Hill Seminary," at Versailles, Ky. - Visitorl

\section{The Baptists}

The Baptists were one of the earliest and strongest denominations in Nelson County. The Salem Association was formed in 1785 and was composed of the following churches, 2

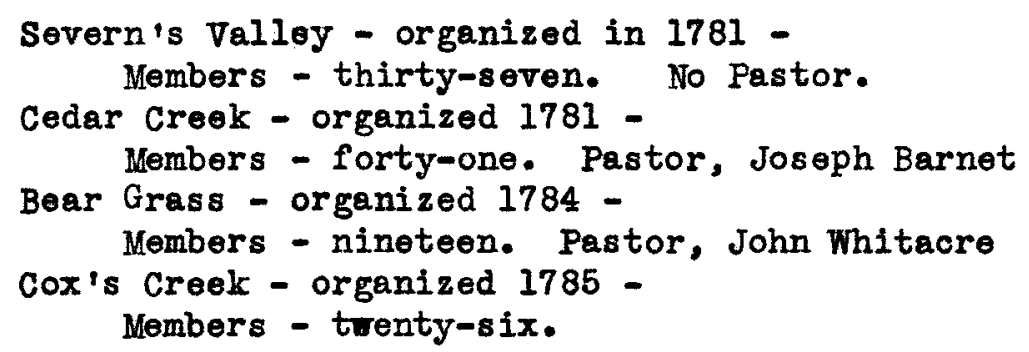

This association continued, with many additions, from neighboring counties until 1849 when the Nelson County group withdrew and formed the Nelson Association of United Baptists. Baptists have always felt that it was the spiritual fitness, not education, that made the minister. For this reason the sect had often been accused of lack of interest in education. Abner W. Clopton expressed the sentiments of Baptists when he said,

1. The Bardstown Saturday Gazette, July 7, 1860.

2. Minutes of the Salen Association, 1785, p. 2 . 
They have never deemed classical learning essential to success in the gospel; and, doubtless, some among them have undervalued its influence; but they have in general prized it, sought it, and endeavoured, under great disadvantages it is admitted, to diffus $\theta$ its benefits. -..- Educationcan neither make a Christian or a minister; but it has its place in the providence of God, in furthering his glory and promoting the happiness of man.l

In 1855 the Nelson Association inserted the following

in its Minutes.

Resolved, That this Association take such steps as shall be necessary to the establishment of a permanent high School in Bardstown, and that W. Vaughan, P. B. Samuels, A. King, J. M. Bell and L. MeKry, be appointed a committee to pursue such course as in their judgement will be best calculated to accomplish the object.?

But evidently Bardstown had enough schools at this time

for the next year the committee reported unfarorably and was

discharged. Although no mention is made of such a move, Bloom-

field must have been selected instead of Bardstown for the school

which in later years was known to those of the comnunity simply

as the Baptist Academy, was evidently begun in 1856.

From the Minutes of Nelson Association of United Baptists,

1857 we find,

Whereas; The Bloomfield Collegiate Institute (for the education of young ladies) under the care of $\mathrm{H}$. B. Wayland, has been conducted successfully, and to the satisfaction of the patrons, while under his care--

1. Photostat extracts from A Memoir of sbner W. Clopton, A.M. by J. B. Jeter, in the Library of the Baptist Theological Seminary, Louis ville, $\mathrm{Ky}$.

2. Minutes of Nelson As sociation of United Baptists 1855, p. 3 . 
Resolved, That this Association recommend the Institution as worthy the patronage of all who may have daughters to educate.

Resolved, That the prospectus of the Institute

be appended to the Minutes of the Association. 1

In the year 1859 the Association urged all friends of the Institute to meet for the purpose of devising such means as thought best to adrance the school. And in 1860 the group announced the new head of the school, Mrs. E. S. Phillips.

The Nelson County Beptists also supported the Georgetown

College as the Minutes of 1850 prove.

Resolved That in the judgement of the Association, Georgetown College, as a Literary Institution, is worthy of the support of our denomination, and wo recommend it to the consideration of all wishing to obtain an education to fit them for the various stations in life.2

And in 1851.

Whereas, in the opinion of this Association, Education is the handmaid of Religion and of great importanoe to the Ministry and to society in general, therefore

Resolved, That we approve of the plan proposed by the Trustees of Goorgetown college, to erect a hall for the accommodation of students in humble circumstances, so reducing the price of board that they may enjoy the benefits of a college course; and that we recommend to the female members of our Church to contribute for the above named objects, and that the Pastors of our churches present this to their ohurches. 3

Another writer of Baptist history says

... The first classical school taught in Kentucky, was established by Elijah Craig, a distinguished Baptist preacher, at what is now Goorgetown, the first of Jamary, 1788.4

1. Minutes of Nels on Association 1857, p. 3 .

2. Minutes of Nelson Association 1850, p. 4.

3. Minutes of Nelson Associetion 1851, p. 5 .

4. J. H. Spencor, A History of Kentucky Baptists,

Vol. $1, \mathrm{p} .488$. 
CHAPTER V

NOTEWORTHY TEACHERS AND SCHOOLS OF NELSON COUNTY 
CHAPTER V

Noteworthy Teachers and Schools of Nelson County

Nelson County and Bardstown had other noted schools and teachers beside those with religious connections. Even as early as 1786 records show that a Mr. Shackleford was teaching in Bardstown.1 No doubt his was a primary school taught in the sohoolmaster's cabin.

It was in 1788 that Salom Academy was establishod. This school, which later became one of the outstanding schools of the state, had for its first trustees a group of the most influential men of the county. They were:

Andrew Hynes - A justice of the peace. Later remembered Salem Academy in his will. Tarah Templin - Minister from Washington County. Matthew Walt on - A General in the Revolutionary War. John Steele

Philip Philips - From Pennsylvania. One of the early surveyors.

Walter Beall - A leading merchant of Bardstown George and

Cuthbert Harrison - Brothers from Virginia. Both had secured large sections of land in Nelson County. James Baird - Owner of the pre-emption on which "Baird's Town" was built.

Joseph Barnet - A Baptist preacher who was prominent in Nelson County affairs.

William Taylor - Baptist Minister, who along with Joseph Barnet, was licensed to celebrate matrimony in Nelson County in 1785.2

James Morrison - One of the citizens appointed by the court to supervise the erection of stocks, pillory and whipping post. 3 James Allen 4

1. Lewis Collins, op.oit., Vol, 2, p. 35 .

2. Minute Book A, op.cit., p. 1 .

3. Ibid., p. 21 .

4. The frequent mention of these men in the Minute Book $A$, indicates their prominence in the community. 
The Academy was fortunate in securing as its first teacher and head, James Priestly. 1 Dr. Priestly was a man of note, the brother of the "distinguished $\mathrm{Dr}$. Joseph Priestly of England."n2 James Priestly was of such ability and character that later the school was known as "Dr. Priestly's School" rather than by its proper name, Salem Academy.

The first notice of the school's opening was announced in the Kentucky Gazette.

The subscriber being appointed by the trustees of Salem, the seminary of learning at Baird's Town, to superintend and conduct the education of students there, is desired to inform the public that Latin, Greek, and English Languages, with the several Arts and soiences commonly studied at Academies and colleges in this country, will be taught from the twentieth instant by

$$
\text { James Priestly }
$$

N.B. The price of tuition will be E5. a year, 20 s in money, and the rest in cattle and country produce in money price. 3

Among the pupils who received part of their education at Salem Academy under the direction of Dr. Priestly were John Allon, Joseph H. Daviess, John Rowan, Felix Grundy, Archibald Cameron, John Pope, and Benjamin Hardin. These men, who were strong in their praise of Dr. Priestly, later achieved much in the public Iife of Kentucky.

It is not known just how long Priestly remained at Salem Academy but the time must have been somewhere in the neighborhood of ten years or longer for he left Kentucky to conduct "with

1. Travis Edwin Smith, The Rise of Teacher Training in Kentucky, p. 22.

2. Lucius P. Little, op. cit., p. 14.

3. The Kentuoky Garette, Norember 22, 1788 . 
distinguished reputation" a private academy in Baltimore some years previous to 1803.1 He was in Bardstown in 1791 as was shown by an advertisement for the school.

At Salem Seminary in Beardstown the Academical studies of youth, are now conducted by Mr. James Priestly. The price of instruction is fire pounds a year, one fourth part to be paid in money. students may board in town on moderate terms for provisions.

Published by order of the Board of Trustees Cuth. Harrison, Sect.2

Felix Grundy, close friend of Andrew Jackson and a noted lawyer, formed a lasting tie with Dr. Priestly through his period of schooling at Salom.3 Grundy left Kentucky for Tennessee where he became prominent. When Baltimore College, which was the development of the academy kept by Dr. Priestly after he left Kentucky, was chartered in 1804, Dr. Priestly was made its first president.4 But by 1809, Felix Grundy had persuaded his old schoolmaster to leave Maryland for Tennessee and to accept the presidency of Cumberland College, later Peabody College, in Nashville. Here again Dr. Priestly served with distinction until his death in 1821.

Salem Academy must have meant much to Bardstown and its inhabitants. One of its first trustees gave the land for its use in 1799 .

1. Travis Edwin Smith, op. oit., p. 22 .

2. Kentucky Gazette, Warch 5, 1791.

3. A. L. Crabb, The Genealogy of George Peabody College for Toachers. p. 14 .

4. Bernard Steiner, History of University Education in Maryland. p. 19 . 
Know all men by these present that I, Walter Beall, Sen. of Nelson County in the state of Kentucky for the encouragement of learning and for divers other good causes and considerations to me hereunto have given granted and confirmed and by those presents do for my selfe and my heirs give grant and confirm unto Wm. Taylor, Andrew Hynes, Michael Campbell, William Whitaker, Benjamin Grayson, Burr Harrison, Walter Beall, Charles Campbell and Joseph Lewis, Trustees of the Bairdstown Academy \& to their Successors one acre and a half and twenty perches of land situated in the said County of Nelson and Adjoining to the Bairdstown preemption to include the said Seminary and to be for the sole use thereof. . . . to said Beall and his heirs the use of the Spring included in the said lot of land provided they do no injury to the said spring. 1

Again, another of Salem's trustees remembered it in his

will. This document is of interest for it reveals that while

the academy was in operation, in rented quarters perhaps, in 1788 ,

the erection of its buildings had been long in the making and by

1800 were not completed.

- - being desireous that the Salem Academy

should be encouraged and the present building for

that purpose compleated I bequeath and give unto the trustees of said Academy five hundred acres of land lying in Hardin County on the waters of clifty and being the half of a thousand Acre survey in the name of Hynes \& Ferry on the following conditions (to wit) that provided the trustees of said Academy causes the walls of the present building to be compleatly raised and covered within twelve months from this date that then the above five hundred Acres of land to be appropriated by the said Trustees towards the finishing the inside work in such way as shall be deemed most beneficial \& advantagious - and It is my intentions to give my right title \& interest only and that neither me nor my heirs to be accountable or liable to make good the land or any part thereof in case the said trustess

1. Deed Book, 5, Nelson County, p. 478. 
should not cause the said buildings to be raised \& covered as afforsaid then and in that case the said five hundred acres of land is to revert back to my children and to be Equally divided between them all. I

Just how long Salen Academy was in existence is not known, but evidently after Dr. Priestly's departure the school began to decline. Whether the building on the Beall land was ever finished with the money given by Andrew Hynes is not definitely known, but as late as 1836 a building known as "The 01d Seminary" was spoken of and this seems to indicate that it was completed.2 When the school was in its heyday, under Dr. Priestly, it won fame and highest reputation for both Bardstown and itself.

Over near Springfield in 1788 , there settled a family which was to produce one of Kentucky's famous men, Ben Hardin. The elder Hardin, who wanted the best for his children, quickly erected a schoolhouse on his place and himself taught a charity school. 3 The children of the poor of the neighborhood attended this school. The Hardins, who had come from Virginia, were educated peoplo. Young Ben received his early schooling from subscription sohools in the vicinity.

In that period and locality the schoolmaster was abroad but seldom. Ichabod Radley taught at Hardin's settlement, in Nelson County not far from 1790. Mr. Hardin was one of his pupils and so were Robert and Charles A. Wiokliffe and Samuel Haycroft. He also, about the same

1. Will Book A, Nelson County, p. 419.

2. Bardstown Herald, Wednesday, February 17, 1836.

3. Lucius P. Little, op.cit., p. 11. 
period, attended a school taught on Cherry Run. This school was by an educated Irishman named Knott, the grandfather of a Kentuoky governor.1

Those who did not send their children to school often employed tutors. Daniel Barry, an Irish refugee who had to flee his country for his participation in an uprising against tho British yoke, was an accomplished scholar. Well grounded in the languages he also was "a polished gentleman." 2

He became a tutor of note. Ben Hardin was accepted by him for a year's tuition. But Barry was compelled to leave Bardstown in 1801 because of justifiable homicide. He went to Danville where his trial was held because "unusual prejudice and party spirit prevails at Bardstown," and was acquitted.3 But neither his reputation as a teacher nor his personal standing suffered because of the unpleasant occurrence at Bardstown, because he immediately secured a position at Hartford Academy where Ben Hardin followed him. Here, Hardin assisted in teaching English in return for his tuition in Groek and Latin. In 1806 , Barry removed to Hopkinsville where he continued teaching. At this time he was considered as one of the greatest classicists in the whole state of Kentucky. 4

Dr. Joshua Lacey Wilson, the Presbyterian minister, was another well known tercher. He was uneducated, except for a little

1. Ibid., p. 14 .

2. Tbid., p. 15.

3. Ibid., p. 15.

4. W. $\mathrm{H}$. Venable, op.cit., p. 163. 
training given him by his mother, until he was twenty-two years of age. He had worked as a blacksmith but at twenty-two he sold his farm and enrolled at Pisgah Academy, Woodford county, in 1794. Later he became a teacher at Frankfort and in 1800 studied with Rev. Vance on Beargrass, Jefferson County, and at the same time taught in Vance Classical School. I

Rev. Wilson taught school in Bardstown in an old $10 \mathrm{~g}$ schoolhouse at the north end of Second Street between 1804 and 1808.2 Then he was called to the First Presbyterian Church in Cincinnati. He remeined there for many years.

For thirty-eight years he was at the head of overy social, moral and intellectual onterprise of the day in Cincinnati, and to his personal influence Cincinnati College is largely indebted for her existence and prosperity. 3

The Draper Kentucky Manuscripts throw much light upon the ability, quality and character of this Bardstown schoolteacher.

Dr. Joshua L. Wilson wrote a piece "When Was Vaccination First Introduced into Kentucky?" Dr. wilson probably instrumental in its introduction into that state. He also wrote pieces on the Grundy anti-bank side of Rentuoky politics in opposition to the clay-bank side.4

In another interviow we learn that-

Dr. Wilson always took sides. After he went to Bardstown he did so, in a case of a trial for murder. At Bardstown he bought a Negro woman. 5

1. Robert Davidson, op.cit., p. 364 .

2. Nora L. MeGee, Tales of old Bardstown.

3. Robert Davidson, op.cit., p. 366.

4. Draper Collection of Kentucky Manuscripts, No. 15cc210, Shane Interview with Dr. Samuel R. Wilson.

5. Ibid., No. 14CC146, Shane interview with Dr. and Mrs. Thomas Cleland. 
A Frankfort newspaper of 1805 also brings to light a side of Dr. Wilson's character. Evidently the paper carried on quite a lively correspondence between Dr. Wilson and a Mr. Nugent.

Dancing Master versus Preacher

Being well informed that Mr. Wilson, the preacher (also Bardstown teacher) of Damnation to Dancers, maintains that in my exhortations to him to learn to spell, * I betrayed ignorance of Grammar in these instances; "if he has; if he wishes," and understanding, that $\mathrm{Mr}$. Wils on is president of the Bard's Town Academy, I call on the Trustees to see that the charge of ignorance attach to him who has deserved it. The anonymous scurrilities with which Mr. Wilson instigated his pupils to assail me, I disdain to notice, further than as they charge me with ignorance of Grammar, which imputation coming from a president of an Academy, however in my opinion he disgrace the title, I, as a professor of Literature, cannot in honor overlook.

I have an established reputation as a teacher of Languages, in the cities where teachers know how to spell, and have learned grammar, not merely from books for children. I have imparted a more oritical knowledge of grammar to young ladies hardly in their teens, than any man erer attained under Mir. Wilson, or than he himself possess. I challenge $\mathrm{Mr}$. Wilson to stand an examination with me before philologists, and if I do not prove that I am able to teach him English, French, Latin \& Greek, may $I$ be as contemtible to men of erudition, as a teacher who cannot spell, and who teaches false grammar, is to

*"Beads, Beadsteads, Togather"

H. P. Nugent

"From their works, ye shall know them"l

The Chancery suit of Daniel Rogers, guardian for Ezeklel Henning and David Henning, versus Richard Conner and Henrietta, his wife, throws some light on the schools of the Burnt station 
settlement. This suit was filed in Nelson Circuit Court, April 23, 1808. Conner had married Henrietta Henning, widow. She had two children involved in the proceodings, Ezekiel and David Henning. The suit was for an accounting for some personal property coming to the two minor children.

Depositions were taken from various sohoolmasters to whom the boys had gone to school. In the opening of the case the following extract discloses that the subscription school was functioning in that neighborhood.

- - your orators [Ezekiel and David] show also that they laboured faithfully for the Defendants [the Conners] until your orator Ezekiel was of the age of 20 years, and orator David of the age of 18 years; and during that time, although the Defendant, Richard Conner, in order to give a following to his conduct, frequently subscribed to schoomesters, yet your orators never enjoyed the benefit of such subscriptions being too closely confined to labour.1

The depositions given below, by the schoolmasters, were

taken at the time and places named.

Taken before Nicholas Minor and Captain Joseph Bane, both Justices of the Perce for Nels on County, Kentucky, at the house of Armistead Hubbard in Bairds Town, the 19th day of July, 1806. Robert Steward deposeth and saithQuestion by Daniel Rogers; When you taught school in the wilson settlement ${ }^{2}$ what scholars did Mr. Richard Conner send to you?

Answer; Nancy and Polly Conner, and some little time he sent Tommy Conner.

1. Book D, Office of Clerk of Nelson County, Kentucky, Circuit court.

2. This was in the Bloomfield neighborhood, then called Middleburg. 
Question, When Ezekiel Henning came to you

on Plum Run ${ }^{1}$ how far was he advanced in learning?

Answer, He could read tolerable well and

wright a lotter.

Question; Did you think Ezekiel Henning

apt to learn at the time he went to you?

Answer; From the time he came to me I am

inclined to think he would learn from the

attention he paid to business.

(Signed) Robert Stewart ${ }^{2}$

All three of the following depositions were taken at the

house of Mrs. Lansdale in Bairds Town, the 18th day of June, 1808,

before the same Justices of the Feace.

Overton Cosby deposeth and saith, 3

Question [by Richard Conner]; Did I not sign

to your school in the year 1802 two scholars?

Answer; You did, and paid me for them. You

signed the two and sent your little daughter only

which I suppose came as much as three months and

Ezekiel Henning came 2 or 3 weeks, and for nine

months David Henning came off and on, but I cant

say he vame constant.

Question; For what reason did Ezekiel Henning

leave your school?

Answer; Master Henning would not comply with

the artacles of my school. I expell ed him from it.

(Signed) Overton Cosby

William Hughes deposeth and saith, 4

Question [by Richard Conner]; What do you

recolleot of my subscribing scholars to your school?

Answer; I find by an article in my possession

that you signed two scholars for nine months in the

year 1793 which was Elizabeth and Ezekiel Henning.

Question; Did not David Henning come to school

to you and at what time did he come?

Answer; David Henning when very young came to me

for which $\mathrm{MA}$. Conner paid me a bushel of Hempseod,

but I can't now Recollect in what year or how long. but am convinced it must have been subsequent to the year 1793.

1. Plum Run is a branoh of Simpson's Creek.

2. Book D, op.cit., p. 308.

3. Ibid., p. 405.

4. Ibid., p. 405. 
Question; [by Mr. Conner]; Did not you suppose that my scholars sent to your school was generally well clothed and well provided with Victuals?

Answer; I did.

Question; What did I pay you for schooling

Ezekiel and Elizabeth Henning?

Answer; What was thon the equivalent to five dollars per scholar.

(Signed) William Hughes

Ignatius Metcalf gave two depositions. I

Question [by conner]; What do you recollect of the scholars signed by me to your school in the year 1805?

Answer; I recollect that $M r$. Conner signed two or three scholars and paid 40 shillings per year each and that David Henning was one but did not come till the ensuing spring and $\mathrm{Mr}$. Conner paid me for the schooling of which I considered David Henning one scholar.

(Signed) Ignatius Metcalf

Of another school taught by him, Metcalf says,

I commenced school in 1802 and finisht my year in 1803, and David Henning attended about 3 or 4 months. He began with me in two syllables and can now go through his spelling book with it in his hand as far as threo syllables and in order to forward him as fast as possible at all spare times I put him to writing.

Nelson County's early history contains much that was outstanding in the educational field and Zachariah Riney, Abraham Lincoln's first sohoolteacher is numbered among the group of educators.

The Riney family belonged to the group of Catholic families that came to Kentuoky about 1785 from St. Mary's County, 
Maryland. They settled in the Pottinger's Croek vicinity. By 1795 Thomas Riney, the father of Zachariah, had died and from his will we learn that he was a slave owner. The will states that the Negroes of which he died possessed should not be sold out of the family of his children.l It is doubtful if zachariah Riney, slave owner, influenced Lincoln, his pupil, against the institution of slavery.

Before the Lincoln family left Kentucky, Abrahom and his sister were sent for short periods to the schools of the neighborhood where Riney was their first teacher. The Lincolns then lived on the road from Bardstown to Nashville, Tennessee, near the Atherton's ferry on Rolling Fork. Zachariah Riney lived on the Nelson County side of Rolling Fork on a farm he had bought in 1811. Part of this land had originally been owned by the pioneer, Joseph Hanks. The $\log$ schoolhouse in which Riney taught Lincoln in 1815 was across Rolling Fork in the Knob Creek section about two miles from Riney's farm.

Little is known of Riney's qualifications as a teacher. He had been educated in Naryland and was thirty years old before he came to Kentucky. The specimens of his handwriting on early court records indicate that he whs a man of some education. He must have been about fifty years of age when he became Lincoln's teacher. The testimony of his grandson says that Riney was a

1. Lincoln Lore, Bulletin of the Lincoln Historical Research Foundation, Bulletin 52, April 7,1930 . 
teacher by profession and he evidently taught many sohools in Nelson and Hardin counties.

As to his character, little reference is found. He was involved in several lawsuits, one with his own family over the settlement of his father's estate, another over the purchase of some land. A deposition taken in $1817^{1}$ states that Riney was well versed in little tricks, that his father was an excellent man and that the deponent believed that Riney was well acquainted with the land situation at the time of the deal and had no grounds for the suit. But this testimony was no doubt prejudiced against Riney.

The Riney femily had no reminiscences of whether Abraham was an apt student. In the short time he attended school on Knob Creek under Riney he could have learned little more than his letters and perhaps beginning steps in reading. Dilworth's New Guide to the English Tongue was Lincoln's first school book.2 The grandson of Zachariah Riney, who was affiliated with the Trappist Order at Gethsemani, wrote thus of his grandfather's last days.

Brother Benedict's grandfather sold his place in Nelson County about 1830 and bought a farm in Hardin County at a place now called Rineyville, on which Brother Benedict's father, Sylvester Riney, lived and reared his family. Grandfather lived with my father for nearly twenty-five years. He was my first teacher, as well as Abraham Lincoln's first teacher.

1. Ibid., Bulletin 52, April 7, 1930.

2. Ibid., Bulletin 283, September 10, 1934. 
Brother Benedict can say that he learned much of what he knows from him, and as I liked him very much a great part of my childhood was spent with him.1

When Riney was 94 years of age he retired to Gethsemani where he died.

A Mr. Mccoffield, an Irish schoolteacher from Ulster, taught in the Pottinger family in the Pottinger's Creek settlement for about five years, from 1832 to 1837.2

This same family, T. J. Pottinger, George W. Pottinger and their brother-in-law, Dr. Joseph E. Settle, provided the funds and had erected by William Riggs, a schoolhouse in the Gethsemani neighborhood in 1840.3

The teacher was paid and boarded by the above men. The school was open to and attended by the children of the vicinity, both Protestant and Catholic, and was available for preaching services to all denominations. Three of the early teachers were Joseph Martin Abell, Miss Julia Settle (daughter of Dr. Settle) and Butler Remey Pottinger, who taught the school about two years. Bardstown, as an educational center, had its native inhabitants strongly behind its efforts. The storekeepers, the housewives, along with the schoolmasters, cooperated to promote its success. Books were advertised by the merchants.

1. Ibid., Bulletin 52, April 7, 1930.

2. From the Manuscript Collection of Nelson County History in the possession of Samul Forest Pottinger, Washington, D. C. 3. Interview with Mr. Samuel Forest Pottinger. 


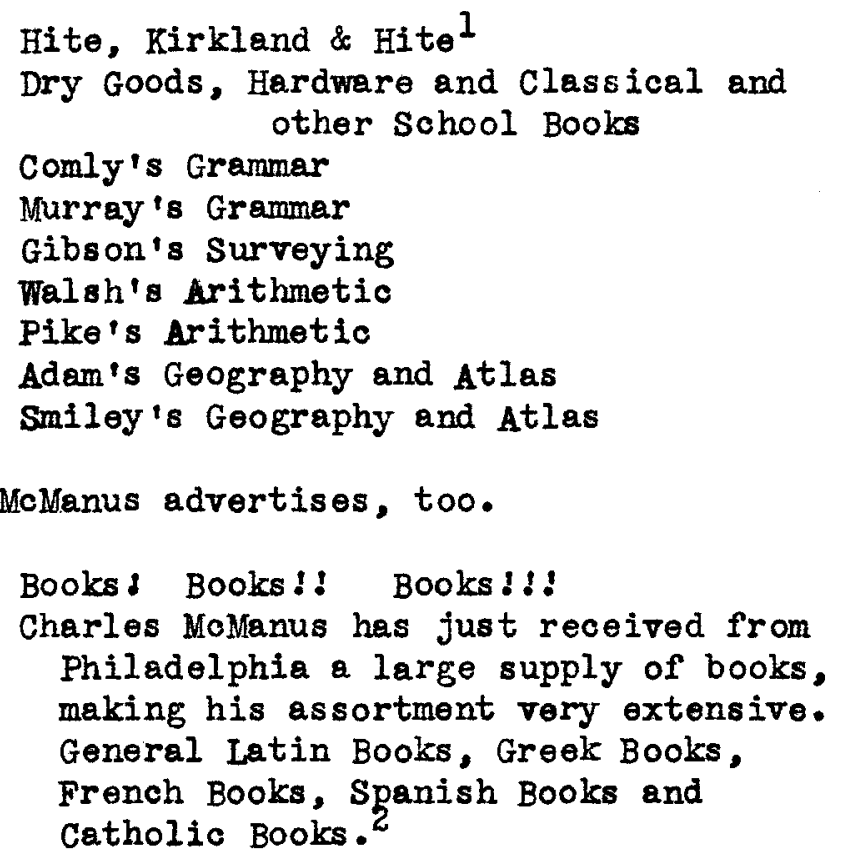

Mrs. Ann Bard does her part also.

Private Female Boarding House

Some eight or ten young ladies who wish boarding for the purpose of attending school, may bo accommodated with Mis. Ann Bard, who will use every means to make them neat and comfortable.3

The early newspapers periodically carried the announcements of the establishment of schools in the various localities under the heading "Education."

The subscriber has opened a school for the instruction of both sexes, in the Poplar Flat Academy, six miles East of Bardstown. The branches will be the same as are usually taught in the best seminaries. Good boarding can be had in the vicinity of the Academy on reasonable terms. J. Wood wi]s $\mathrm{cn}^{4}$

1. Western Herald, Wednesday, December 10, 1828.

2. Ibid., Saturday, December 8, 1832.

3. Ibid., May 25, 1831.

4. The Bardstown Herald, Monday, February 29, 1836. 
The following advertisement is interesting in that it implies that the instructor was a man of no little background and experience to judge from the spread of subjects to be taught. Eleven months for a school term was also unusual for a county school.

On the 4th day of January, 1836, a school will be opened in Mrs. Stoner's School House, seven miles North West of Bardstown, and conducted, during the ensuing term of eleven months, by William sims, who will teach Orthography, Reading, Penmanship, Arithmetic, Natural Philosophy, and the Elements of Euclid, Geography, Geometry, English Grammar, Trigonometry, Surveying, Rhetoric, Algebra and Astronomy. For terms (which will be accommodating) apply to teacher.

Boarding will be furnished to young men from a distance, if required. 1

In the Bloomfield vicinity the Big Spring Academy adjoining Big Spring Church, was first a parochial school under the Presbyterian control. The church was established in 1794 and as early as 1810 there was a primary school there, no doubt taught by the minister of the church as was the presbyterian custom.2

At Bloomfield the Bloomfield Collegiate Institute, or Baptist Academy took care of those local children who were not sent to Bardstown. H. B. Wayland was the first teacher, followed by Mrs. Sue Phillips, Miss Ema Simpson and later the Reverend Ball. 3

At Boston, a small community to the west of Bardstown, a school called "Little Brick" was established well over a hundred years ago. 4

Back at Bardstown, Messrs, Gazlay and Taylor not only

1. Ibid., January 30, 1836.

2. Lewis Joseph Sherilil, op.cit, , p. 123.

3. Interview with $\mathrm{Mr}$. Jodie Brown, Bloomfield, Kentucky.

4. Interview with Mr. Ack Harned?, Boston, Kentucky. 
announce the opening of their school but explein its procedure.

Bardstown High School

Messrs. Gazlay \& Taylor will open a school in Bardstown on the 23rd of Januery, to be taught on the Lancasterian or Fonitorial plan of instruotion. The school will be taught for the present in the upper room of the brick building adjoining $\mathrm{Mr}$. Rentch's tavern.

The Monitorial system of instruction is briefly this; The pupils are classed according to their qualifications. Each class, c ontaining five or six pupils has its monitor, who is selected from these pupils who are most advanced in the branches studied by it; and who wish to study them more critically. When the number studying any branch is such as to require it, two sets or classes of monitors are selected, of which the one is instructed by the preceptor, while the other is attending to their respective classes alternately. Thus the monitors are acquiring both the theoretical and practical parts of education.

At the $\operatorname{clos} \theta$ of every recitation, the lesson is given for the following day, which the pupils are expected to prepare.

This mode of instruction has eminently the advantage of exciting interest in study and rendering the acquisition of knowledge pleasant, which is of the utmost importance to the instruction of youth.

The studies will be as follows,

Introductory Department

Reading, spelling and writing

Junior Department

Reading, spelling and writing continued

Arithmetic, Goography, English Grammar

Bookkeeping, Composition and Declamation

Senior Department

Junior Studies completed, History, Natural

Philosophy, Rhetoric, Logic, Algebra,

Trigonometry, Geometry, Surveying, and the

Latin and Greek Languages.

Terms for Tuition are

Introductory department ......\$3.00

Junior do $\quad \cdot . \cdot \cdot \cdot \$ 5.00$

Senior do $\quad . . . . . \$ 8.00$

per quarter of twelve weeks, paid quarterly.

The pupils will be taxed 25 cents each to defray the expense of fuel.

1. Western Herald, January 19, 1833. 
One teacher, Thomas Humphreys, inserted his recommendations in the locel paper. He was from Virginia where he had secured his education and had taught.

Fredericksburg Classical Academy June 15,1830

Mr. Thomas J. Humphreys has been a student in this seminary two quarters; during this time he has read Ovid, and a portion of Horace, Juvenal and Livy. He has studied Euclid. Mr. H. has been remarkably attentive to his studies and has made the best use of his time. I consider him a good Latin scholar, and take pleasure in stating that his deportment has been unexcelled. Thos. H. Hans on. 1

Mr. Humphreys and his brother John proposed to open their school in the old seminary building, near Bardstown, which no doubt was the building referred to in Androw Hynes' will, the old Salem Academy. If some of the above teachers and schools made their charges for tuition seemingly small, the market quotations for that day were likewise low, so that the price of education was apparently in line with the general cost of living.

Bardstown Prices Current (Corrected weekly) ${ }^{2}$

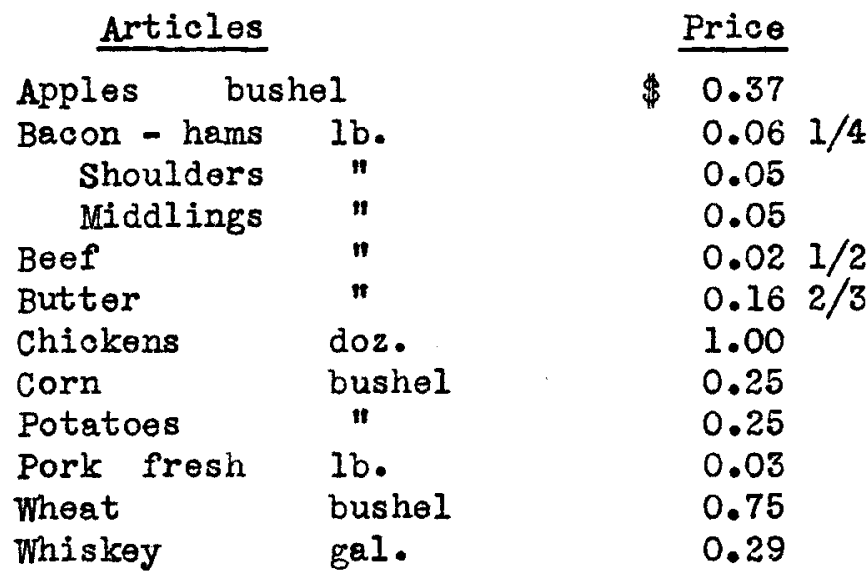

1. Ibid., Saturday, Fobruary 9, 1833.

2. Ibid., Saturday, November 10, 1832. 
CONCLUSION 


\section{CONCLUSION}

Kentucky pioneers, especially a large number of those who settled Nelson County, brought with them culture, education, and refinement. Those who lacked these advantages were conscious of them to the extent that they desired them for their children. These people encouraged the growth of schools, beginning with the fort school, the mold Field School," through the county Acadeny plan, the Private Academy movement and on into a public sohool system.

This system developed slowly but steadily. The General Assembly of Virginia gave it its start with the establishment of Transylvania. Several of the state's early governors included the need of such a system in their messages to the legislators. Various plans were tried and as one failod another took its place. When the common schools were finally introduced the undertaking was slow in getting under way. Its most serious drawback was the lack of backing from those of wealth. This class had always secured private instruction, either with tutors or at private schools, for their children and so felt no urge for a more enlarged system of education for all. Another hindrance was the indifference of the general public toward a plan that needed support in the form of increased taxes.

Nels on County from its formation in 1785 up to the Civil War period was the source of superior educational opportunities. 
Its institutions were of such caliber that their splendid reputations were known not only throughout the state of Kentucky but extended to the West and through the South.

From its beginning, Nelson county was fortunate in having religious elements which $r$ ecognized the need for and value of oducation. The Catholics, Methodists, Baptists and Presbyterians early promoted educational facilities.

Nelson County was the center of the Catholic religion west of the Allegheny Mountains for the most of the pioneer period. Bardstown was early made the see and as such greatly influenoed the spread of Catholic educational institutions in the neighborhood. The early priests, Bishop Flaget, Father Badin, Father Nerinckx and Father David were men who had received their own education in European centers of culture. Bishop Flaget and Father David were both eminent educators, with years of teaching experience in their native country, France. These men were quick to recognize the need and encourage the growth of schools.

Such schools as St. Thomas' Seminary, St. Joseph's College, Nazareth and the institutions oonducted by the Lorettines were of the first rank and helped make Nelson County noted for its educational opportunities. Loretto, just across the county line in Marion County, receives recognition with Nelson County schools, not only for its nearness but also for its branch schools, Gethsomani, the primary school, and the parochial school at Fairfield. The work of the 
Sisters of Loretto with the deaf and dumb was likewise a reflection of the awareness of the Catholic school heads of the necessity of aid for the handicapped.

Men of recognized educational ability gained much of their reputation as educators during their stay in Nelson County. Beginning with Dr. James Priestly, such men as Dr. Joshua Lacey Wilson, Dr. Nathan Rice, Dr. Vernon J. Cosby and Professor Louis Hast won fame for themselves, based upon their Nelson County experience, in larger fields and in other states. The schools and communities were certainly richer for having such men of culture and ability as heads of their institutions.

Bardstown, in 1788, was selected as the place for one of the early county academies, Salem. This noted school educated many of the most prominent men in Kentucky's history. Bardstown soon became an educational center. The Catholic institutions, St. Thomas' Seminary, St. Joseph's College and Nazareth Academy drew students to the little city from the South and West. At the same time the Methodist Bardstown Female Institute and the Presbyterian Bardstown Female Academy or Roseland rivaled the best of girls' schools.

The opening of the Civil War saw the beginning of the decline of Bardstown's schools. But for a period of seventy years and more -from 1788 when Salem Academy was opened until the Civil War -Bardstown and its institutions were a source of pride to Kentucky. 
APPENDIX 


\section{APPENDIX}

Early Teachers of Nelson County

Date

1785

1786

1788

1790

1790

1793

1798

1800

1800

1802

1804

1805

1811

1811

1820

1821

1831

1831

1832

1832

1832

1833

1833

1836

1836

1836

1840

Joseph Martin Abell

After Miss Julia Settle

1840 (?) Butler Remy Pottinger

John Moore

Mr. Shackleford

Dr. James Priestly

Ichabod Radly

Mr. Knott

William Hughes

Father de Rohan

Robert Steward

Daniel Barry

Overton Cosby

Dr. Joshua L. Wilson

Ignatius Metcalf

Zachariah Riney

Father David

Rev. Elder

Dr. Kenrtok

Le Grand Rucker

John Farmer

Dr. Nathan L. Rice

$$
\text { (Presb.) }
$$

Mr. McCoffield

T. X. McAtoo

William Sims

J. Wood Wilson
School

Place

Salem

Subscription

William McReynolds (Meth.)

Messrs. Gazlay and Taylor

Thomas and John Humphrey

Subscription

Subsaription

Subscription

Subsoription

Tutor

Subscription

Subscription

Subscription

Subscription

St. Thomas' Seminary

St. Joseph's College

st. Thomas' Seminary

Subscription

Subscription

Bardstown

Female Academy Bardstown

Bardstown

Female Academy Bardstown

Tutor

Bardstown High School

Subscription

Subscription

Subscription

Poplar Flat Academy

Pottinger's School House

Pottinger's

School House
Pottinger's

Settlement

Bardst own

Bardstown

Bardstown

Hardin's

Settlement

Cherry Run

Burnt Station

Salt River

Wilson's

Settlement

Bardstown

Burnt Station

Bardstown

Burnt Station

Rolling Fork

Section

Four miles

So. Bardstown

Bardstown

Near Bardstown

Bardstown

Bardstown

Bardstown

Bardstown

Bardstown

Mrs. Stoner's

School House

Seven miles N.W. Bardstown

Pottinger's

Settlement

Pottinger's

Settlement 


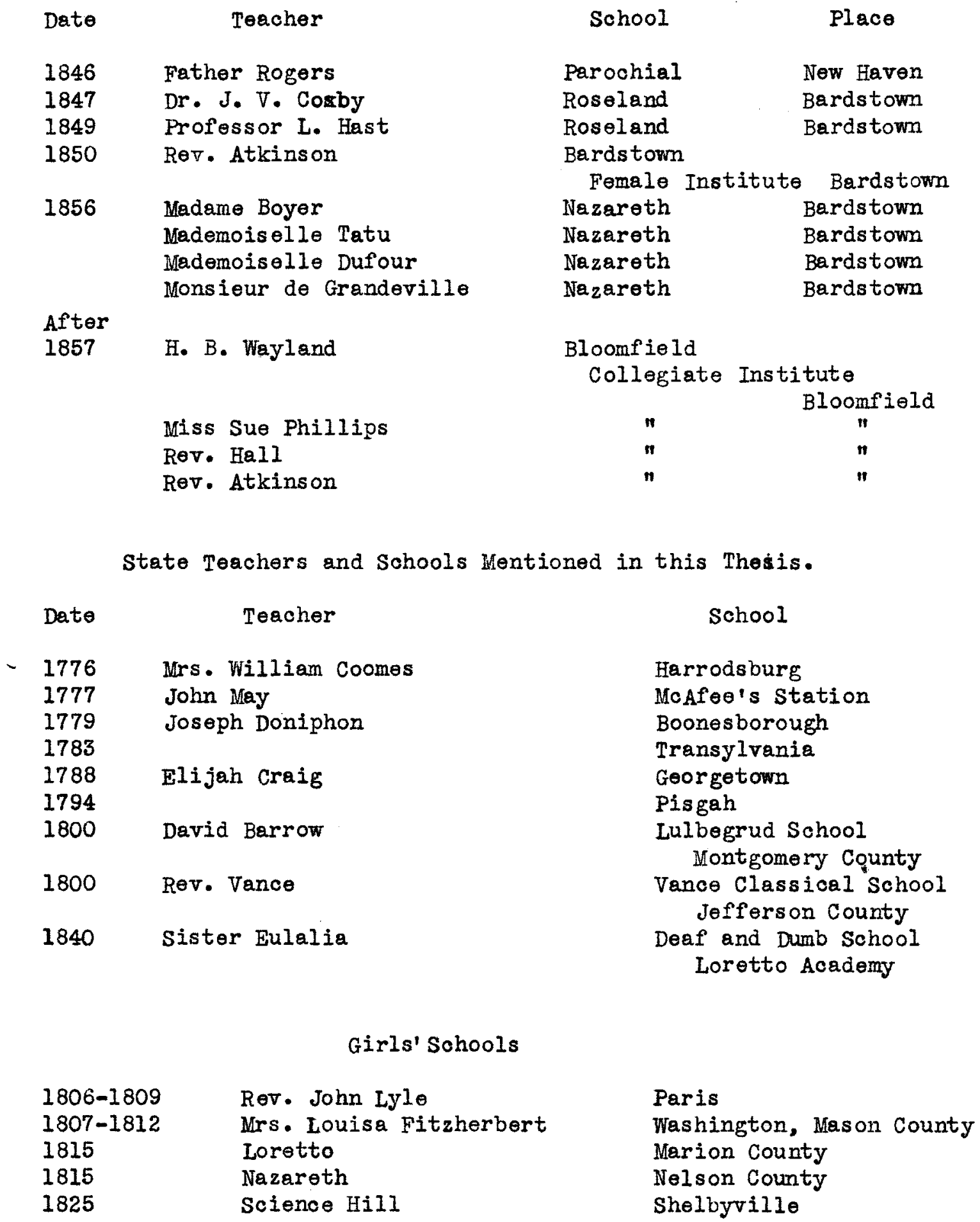


Nels on County Sohools

Date

1788

1788

1795

1805

1808

1810

1812

1815

1818

1819

1820

1821

1826

1827

1830

1832

1840

1840

1843

1846

1850

1857
School

Sal om Academy

Hardin's School

Pottinger's Creek School

Trappist School for Boys

St. Barbara's (for girls)

Big Spring Academy

St. Thomas Seminary

Nazareth

Geths emani (for girls)

Bethlehom (for girls)

st. Joseph's College

St. Michael's

St. Thomas' Industrial

School

St. Thomas ' College

Bardstown Female Academy

(Methodist)

Bardstown Female Academy

(Presbyterian)

"Little Brick"

Pottinger's School House

Loretto Female Academy

Father Abell's School

Bardstown Femalo Institute (Baptist)

Bloomfield Collegiate

Institute (Baptist)
Place

Bardstown

Hardin's Settlement

Pottinger's Settlement

Holy Cross

Pottinger's Settlement

Near Bloomfiold

Near Bardstown

Near Bardstown

Pottinger's Settlement

Bardstown

Bardstown

Fairfield

Near Bards town

Near Bardstown

Bardstown

Bardstown

Boston

Pottinger's Settlement

Gethsemani

New Haven

Bardstown

Bloomfie ld 


\section{BIBLIOGRAPHY}




\section{BIBLIOGRAPHY}

Books

Andrews, Matthew Page, History of Maryland. Province and State. New York: Doubleday, Doran and Co. Inc., 1929. $\overline{721}$ pp.

Ardery, Mrs. Wr. B. (compiler), Kentucky in Retrospect, 1792-1942. Sesquicentennial Commission, Commonwealth of Kentucky. $205 \mathrm{pp}$.

Arnold, Rev. W. E., A History of Methodism, Louisville, Ky.: Pentecostal Herald Press, 1935. Vol. I, 429 pp; Vol. II, 329 pp.

Baber, Georgo, Origin of Popular Education in Kentucky. Louisvillo, $\mathrm{Ky}$.: John P. Morton and Co., 1881. $46 \mathrm{pp}$.

Collins, Lewis, History of Kentucky - Covington, Ky.: published by Collins and Co., I882. Vol. I, 683 pp; Vol. II, 804 pp.

Davidson, Robert, History of Presbyterian Church in the State of Kentucky. New York: Robert Carter, 1847. $3 \overline{78} \overline{\mathrm{pp}}$.

Drake, Dr. Daniel, Pioneer Life in Kentucky, Series of Reminiscential Letters to his Children. Cincinnati: Robert Clarke and Co., $1870 . \overline{263}$ pp.

Draper Collection of Manuscripts. Calendar of Kentucky Papers. Madison: Publication of State Historical Society of Wisconsin, 1925. Vol. II, $624 \mathrm{pp}$.

Filson, John, The Discovery, Settlement and present State of Kentucke. Wilmington: printed by James Adams, $1784.118 \mathrm{pp}$.

Hamlett, Barksdale, History of Education in Kentucky. Frankfort: 1914. $330 \mathrm{pp}$.

Howlett, William J., Historical Tribute to St. Thomas' Seminary. St. Louis, Mo.: B. Herder, $1906.1 \overline{97}$ pp.

Inlay, Gilbert, A Topographical Description of the Western Territory of North America. Plccadilly: printed for Debrett, opposite Burlington House, 1793. $433 \mathrm{pp}$.

Jillson, Willard Rouse, Pioneer Kentucky. Frankfort, Ky・: The State Journal Co., $1934.152 \mathrm{pp}$. 
Jillson, Willard Rouse, Kentucky Land Grants, A Systematic Index to all the Land Grants Recorded in the State Land Office at Frankfort, $\overline{\mathrm{Ky} \cdot} \overline{1782-19} \overline{24 .}$ Lou isvi $\overline{l l e}, \overline{\mathrm{Ky} \cdot:} \overline{\text { Standard }}$ Printing Co.. 1925. 1844 pp.

Jillson, Willard Rouse, Kentucky History, A Check and Finding List of all of the Principal Published and Manuscript Sources of the General, Regional, and County History of the Commonwealth 1729-1936. Louisville, Ky.: Standard Printing Co., 1936. 87 pp.

Jillson, Willard Rouse, Rare Kentucky Books 1776-1926, A Check and Finding List of Scarce, Fugitive, Curious and Interesting Books. Louisvilie, Ky.: Standard Printing Co., 1939. $199 \mathrm{pp}$.

Johnston, J. Stoddard, Memorial History of Louisville, Chicago and New York: American Biographical Fublishing Co., 1896. Vol. II, $678 \mathrm{pp}$.

Lewis, Alvin Fayette, History of Higher Education in Kentucky. Washington: Government Printing office, 1899. $350 \mathrm{pp}$.

Ligon, Moses Edward, A History of Public Education in Kentucky. Lexington, Ky•: Ūniversity of Kentucky, 1942. $369 \mathrm{pp}$.

Little, Lucius P., Ben Hardin - His Times and Contemporaries. Louisville: Courier-Journal Job Printing Co., 1887. 640 pp.

Maes, Rev. Camillus P., Life of Rov. Charles Nerinclo. Cincinnati: Robert Clarke and Co., 1880. $635 \mathrm{pp}$.

Marshall, Humphrey, The History of Kentucky. Frankfort: Henry Gore, 1812. Vol. I, $407 \mathrm{pp}$.

Mattingly, Sister Mary Ramona, The Catholic Church on the Kentucky Frontier 1785-1812. Washington, D.C.: Catholic University of America, 1936. $235 \mathrm{pp}$.

Minogue, Ann C., Loretto, Annals of the Century. New York: The America Press, 1912. $252 \mathrm{pp}$.

McGill, Anna Blanche, Sisters of Charity of Nazareth. New York: Encyclopedia Press, 1917. $436 \mathrm{pp}$.

Redford, A. H., Western Caveliers, Embracing the History of the Mothodist Episcopal Church in Kentucky from 1832-1844. Nashville, Tenn.: Southern Methodist PublishIng House, 1876. $552 \mathrm{pp}$. 
Redford, A. H., History of Methodism in Kentucky. Nashville, Tenn.: Southern Nethodist Publishing House, 1868. Vol. I, 479 pp; Vol. II, $512 \mathrm{pp}$; Vol. III, $554 \mathrm{pp}$.

Robertson, George, Scrap Book on Law and Politics, Men and Times. Lexington, Ky.: A. W. Elder, Printer and Publisher, 1855. 402 pp.

Robertson, James Rood, Petitions of the Early Inhabitants of Kentucky to the General Ass embly of Virginia 1769-1792. The Fils on Club Publications No. 27. Louisville, Ky.: John P. Morton and Co., 1914. $246 \mathrm{pp}$.

Shaler, N.S., Kentucky - A Pioneer Commonwealth. Boston: Houghton, Mifflin and Co., 1885. $433 \mathrm{pp}$.

Sherrill, Lowis Joseph, Presbyterian Parochial Schools 1842-1870. New Haven: Yale University Press, 1932. 261 pp.

Spencer, J. H., A History of Kentucky Baptists. Cincinnati: J. R. Beumes, 1885. V01. I, $767 \mathrm{pp}$; Vol. II, $671 \mathrm{pp}$.

Spalding, M. J., Sketches of Early Catholic Missions of Kentucky from their Commencement in 1787-1827. Louisvilie, Ky.:

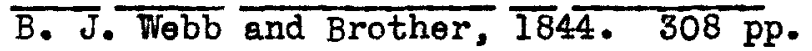

Spalding, M. J., Sketches of the Life, Times and Character of Benedict Joseph Flaget. Louisville, $\overline{K y} \cdot$ : Webb and Levering, 1852. $405 \mathrm{pp}$.

Spalding, Mattingly, Biography of a Kentucky Town. Baltimore, Maryland: Printed by Author, 1942. $86 \mathrm{pp}$.

Smith, Travis Edwin, The Rise of Teacher Training in Kentucky. Nashvillo, Tenn.: George Peabody College for Teachers, 1932. $194 \mathrm{pp}$.

Smith, 2. F., The History of Kentucky. (Fourth Edition) Louisville, $\mathrm{Ky} \cdot$ : Prentice Press, 1901. $963 \mathrm{pp}$.

Steiner, Bernard, History of University Education in Maryland. Baltimore: Johns Hopkins Pres 8, 1891. $73 \mathrm{pp}$.

Sweet, William Warren, Rise of Methodism in the West. The Journal of the Western Conference 1800-1811. Cincinnati: The Methodist Book Concern, 1920. 207 pp. 
Thwaites, Reuben Gold, Early Western Travels. Travels West of the Alloghanies 1793-1796. By Andre Michaux. Cleveland, Ohio: The Arthur H. Clark Co., 1904. Vol. III, 382 pp; Vol. IV, 377 pp.

Venable, W. H., Beginnings of Literary Culture in the Ohio Valley. Historical and Biographical Sketches. Cincinnati: Robert Clark \& Co., 1891. $519 \mathrm{pp}$.

Webb, E. J., The Centenary of Catholicity in Kentucky. Louisville: Charles A. Rogers, 1848. 594 pp.

\section{Legal Material.}

Hening, William Waller, Statutes at Large of Laws of Virginia from 1619. Richmond: Printed by George Cochran, 1823. V01. XII, $832 \mathrm{pp}$.

Hening, William Waller, Statutes at Large - Collection of all the Laws of Virginia. Richmond: Printer - George Cochran, 1822. Vol. $\overline{\mathrm{X}}, \overline{663 \mathrm{pp} \text {. }}$

Littell, Williom, The Statute Law of Kentucky. Frankfort, Ky:: Printed for William Hunter, 1810. V01. I, 753 pp; Vol. II, 630 pp; Vol. III, $621 \mathrm{pp}$.

\section{Articles.}

Allison, Young E., "A Chapter of Trappist History in Kentucky," The Filson Club History Quarterly, Vol. 1, 68-81 pp. 1926-1927.

Stephenson, Nartha, "History of Education in Kentucky," Register of

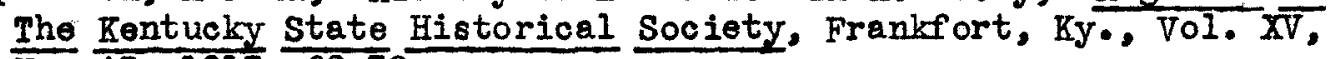
No. $43,1913.69-79$ pp.

Wickliffe, John D., "Pioneer Stations in Nels on County," The Filson Club History Quarterly, Vol. II, 1928, 129-132 pp.

\section{Unpublished Manusoripts.}

Manuscript Collection of Nels on County History in the possession of Samuel Forrest Pottinger, Washington, D.C.

Manuscript Arithmetic made by John Hargis in 1828. The Filson club, Louisville, Kentucky. 
Manuscripts and Ledgers from the Archives at Loretto Motherhouse, Nerinckx, Kentucky.

Letter of Miss Marianna Barkley at The Filson Club, Louisville, Kentucky.

Check List of Kentucky Newspapers, The Filson Club, Louisville, Kentucky. Compiled by Ludie J. Kinkead, The Filson Club and Thomes Clark, University of Kentucky, 1935. Mimeograph copy with later typewritten additions.

\section{Miscellaneous Material \\ Library of Southern Baptist Theological Seminary.}

Minute Books

Minutes of Salem Association, 1785.

Minutes of Nelson Association, 1850.

Minutes of Nelson Association, 1851.

Minutes of Nelson Association, 1855.

Minutes of Nelson Association, 1857.

Photostat extracts from, A Memoir of Abner W. Clopton, by J. B. Jeter, Yale and Wyatt, 1837 .

\section{Pamphlets.}

Crabb, A. L., The Genealogy of George Peabody College, Nashville, Tenn., 1955. $56 \mathrm{pp}$.

Lincoln Lore, The Bulletins of Lincoln Historioal Research Foundation, Fort Wayne, Indiana.

MeGee, Nora L. (compiler), Tales of Old Bardstown. Printed and published under the auspices of the Bardstown Woman's Club, 1925. $24 \mathrm{pp}$.

Dr. Saugrain's Note-Books, 1788.

"Stay Opposite Louisville"

"Observations upon Post Vincennes"

"Diary of Journal from Louisville to Philadelphia"

Worcester, Mass., Eugene F. Bliss, Davis Press, 1909.

21 . pp.

Wickliffe, Robert, Letter to His Constituents, 1825. Frankfort: January $12,1 \overline{825 .} 19 \mathrm{pp}$. 


\section{News papers}

Bardstown Herald

Loret to Motherhouse, Nerinckx, Bentucky January 30,1836

February 17, 1836

February 29, 1836

March 30, 1836

October 28, 1852

Bardstown Saturday Gazette

The Filson Club, Louisville, Kentucky July 7,1860

Candid Review, Bardstown

The Filson Club, Louisville, Kentucky March 22, 1808

Cathol ic Advocate, Bardstown

1118 S. Third St., Louisville, Kentucky August 25, 1838

February 18, 1843

August 5, 1843

Kentucky Gazette, Lexington

The Filson club, Louisville, Kentucky

May 24,1788

November 22,1788

March 5, 1791

June 18, 1791

Louisville Courier Journal

Louisville, Eentucky

October 20, 1926.

The Palladium, Frankfort

The Filson Club, Louisville, Kentucky

December 16, 1805.

Western Herald, Bardstown

Loretto Motherhouse, Nerinckx, Kentucky

Deoember 8, 1828

December 10, 1828

March 2, 1831.

March 30, 1831

May 25,1831

March 24, 1832

November 10, 1832

January 19, 1833

February 9,1833

Western Luminary

The Filson Club, Louisville, Ken tuoky

January 14,1829

March 11, 1829 


$$
\text { Records from the Courthouse, Bardstown, Kentucky. }
$$

Book "D" - Circuit Court

Deed Book No. 5

Minute Book "A" - May 24, 1785 - March 12, 1788.

(A copy of this book is at The Filson Club, Louisville, Kentucky) Will Book "A"

Will Book "C"

\section{Interviews}

Mr. Jodie Brown, Bloomfield, Kentucky.

Mr. Ack Harned, Boston, Kentucky.

Mr. Samuel Forrest Pottinger, Washington, D. C.

Mr. Jack Muir, Bardstown, Kentucky.

Mrs. Carrie Fulton, Bardstown, Rentucky.

Miss Ella Kourenberg, Bardstown, Kentucky.

Mr. Ben Johns on, Bardstown, Bentucky.

Miss Nora L. McGee, Bardstown, Kentucky

Father Durbin, St. Thomas' Church, Bardstown, Kentucky.

Sister Mary Antonnel la, Loretto Notherhouse, Nerinckx, Kentucky

Mr. Walter Kiser, Staff Artist, Louisville Times, Louisville, Kentucky. Judge Samuel Boldrick, Louisville, Kentuoky

Dr. W. O. Carver, Southern Baptist Theological Seminary, Louisville, 